FERNANDO BERTOLETTI BASTOS

ESTADO FEDERAL E JURISDIÇÃO CONSTITUCIONAL

Tese de doutorado

Orientador: Prof. Titular Dr. Elival da Silva Ramos

UNIVERSIDADE DE SÃO PAULO

FACULDADE DE DIREITO

São Paulo/SP

2020 
FERNANDO BERTOLETTI BASTOS

\section{ESTADO FEDERAL E JURISDIÇÃO CONSTITUCIONAL}

\section{Versão corrigida ${ }^{1}$}

Tese de doutorado apresentada à Banca Examinadora do Programa de Pós-Graduação em Direito, da Faculdade de Direito da Universidade de São Paulo, como exigência parcial para a obtenção do título de Doutor em Direito, na área de concentração "Direito do Estado", sob orientação do Prof. Titular Dr. Elival da Silva Ramos

\section{UNIVERSIDADE DE SÃO PAULO \\ FACULDADE DE DIREITO}

São Paulo/SP

2020

\footnotetext{
${ }^{1}$ Versão corrigida da tese apresentada, após a aprovação do autor pela Banca Examinadora, na forma da Resolução CoPGr nº 6018, de 13 de outubro de 2011. A versão original da tese, depositada para a defesa, encontra-se disponível no Programa de Pós-Graduação em Direito da USP.
} 
Banton, Pernando Bertoletti

Ratado federal e Juriwdição Conatitucional Fernando Bertoletti Bantou; orientador Blival da Silva Ramoe -- SSo Paulo, 2020

296

Tene (Doutorado - Programa de PGn-Gradusçäo em Direito do Batado) - Faculdade de Direito.

Univeraidade de Sāo Paulo, 2020.

1. Pederaliamo. 2. Batado federal. 3. Repartiçăo de competencian. 4. Jurindi ça Conatitucional. 5 . Centralizaçăo. I. Ramou, Blival da Silva, orient. II Titulo. 
BASTOS, Fernando Bertoletti. Estado federal e Jurisdição Constitucional.

Tese de doutorado apresentada à banca examinadora do Programa de Pós-Graduação em Direito, da Faculdade de Direito da Universidade de São Paulo (FDUSP), como exigência parcial para a obtenção do título de Doutor em Direito, na área de concentração "Direito do Estado", sob orientação do Prof. Titular Dr. Elival da Silva Ramos

Aprovação em:

Banca examinadora:

Prof.(a.) Dr.(a.)

Instituição: Assinatura:

Prof.(a.) Dr.(a.)

Instituição: Assinatura:

Prof.(a.) Dr.(a.)

Instituição: Assinatura:

Prof.(a.) Dr.(a.)

Instituição: Assinatura:

Prof.(a.) Dr.(a.)

Instituição: Assinatura: 
Essa pesquisa foi realizada com apoio do Conselho Nacional de Desenvolvimento Científico e Tecnológico (CNPq) 


\section{AGRADECIMENTOS}

Agradeço, primeiramente, ao meu orientador, Professor Elival da Silva Ramos, por ter me acolhido no Programa de Pós-Graduação da Faculdade de Direito da USP e por ter acreditado, desde o princípio, em minha pesquisa. Além disso, sou grato pela oportunidade de realizar o estágio em docência, sob sua supervisão, cujo convívio e ensinamentos em sala de aula proporcionaram-me um aprendizado inestimável.

Aos Professores Fernanda Dias Menezes de Almeida, Roger Stiefelmann Leal e Marta Arretche, pelos valiosos comentários que fizeram ao meu projeto de qualificação, pois compreenderam os propósitos da minha pesquisa e fizeram sugestões que contribuíram para que eu pudesse chegar aonde me propus chegar.

Não poderia deixar de agradecer aos funcionários da Biblioteca da Faculdade de Direito da Universidade de São Paulo, que sempre gentilmente me ajudaram a encontrar as fontes que buscava, nesse precioso acervo e bases de dados da USP.

À Faculdade de Direito da Universidade de São Paulo, por ter me proporcionado esses cinco anos de aprendizado intenso, ao longo dos quais revi muitos de meus conceitos, premissas e suposições. Certamente, não sou mais o mesmo pesquisador que ingressou nesta instituição em 2015.

Essa pesquisa não teria sido possível sem o apoio do Conselho Nacional de Desenvolvimento Científico e Tecnológico (CNPq), cujo suporte foi imprescindível para que eu tivesse acesso ao debate internacional mais atual sobre o tema. Espero que esse trabalho possa finalmente retribuir o investimento feito em mim e contribuir para futuras pesquisas na área.

Agradeço finalmente aos meus amigos, que compreenderem minha ausência durante esse período. Tantas foram as pessoas que, de um modo ou de outro, me ajudaram nessa jornada, que me atrever a identificá-las seria um risco de, involuntariamente, esquecer de mencionar algum nome.

Este é o resultado de anos de pesquisa que agora submeto à apreciação da Academia. 
À minha família que sempre compartilhou dos meus sonhos 
"Cada decisão da Suprema Corte, em qualquer questão que surja a respeito da natureza e do alcance do governo federal, afetará os limites da competência dos Estados. À medida que aqueles ampliem o exercício de seus poderes, os desses serão restringidos. Que o Poder Judiciário federal apresentará uma forte inclinação em favor do governo federal, bem como conferirá à Constituição uma interpretação que favorecerá a extensão de sua jurisdição, é evidente por uma série de razões."

(Brutus)

"[O STF é] a instituição equilibradora, por excelência, do regime, a que mantém a ordem jurídica nas relações entre a União e os seus membros, entre os direitos individuais e os direitos do poder, entre os poderes constitucionais uns com os outros sendo esse o papel incomparável dessa instituição, a sua influência estabilizadora e reguladora influi, de um modo nem sempre visivel, mas constante, profundo, universal na vida inteira do sistema." 3

(Ruy Barbosa)

\footnotetext{
${ }^{2}$ Tradução livre para: "Every adjudication of the supreme court, on any question that may arise upon the nature and extent of the general government, will affect the limits of the state jurisdiction. In proportion as the former enlarge the exercise of their powers, will that of the latter be restricted. That the judicial power of the United States, will lean strongly in favour of the general government, and will give such an explanation to the constitution, as will favour the extension of its jurisdiction, is very evident from a variety of reasons." Brutus $\mathrm{n}^{\circ}$ XI (31 jan. 1788). In: KETCHAM, Ralph (Ed.). The Anti-Federalist Papers and the Constitutional Convention Debates. New York: Signet Classic; Penguin Group, 2003, p. 312.

${ }^{3}$ BARBOSA, Rui. O Supremo Tribunal Federal na Constituição Brasileira. In: BARBOSA, Rui. Obras Completas de Rui Barbosa. v. 41, t. 4, 1914. p. 239.
} 


\section{RESUMO}

BASTOS, Fernando Bertoletti. Estado federal e Jurisdição Constitucional. 296 folhas. 2020. Tese (Doutorado). Faculdade de Direito, Universidade de São Paulo, São Paulo, 2020.

Dado que, em Estados federais, a autoridade para resolver disputas envolvendo os limites de competência entre União e Estados é, salvo raras exceções, conferida às Supremas Cortes, essas costumam ser descritas como sendo os "árbitros do federalismo", o que supõe que essas devam ser imparciais em relação a ambas as partes e desinteressadas quanto ao resultado do julgamento. Todavia, como seus membros são em geral nomeados por meio de um processo que envolve tanto o Executivo como o Legislativo, a maioria dessas não podem ser consideradas como independentes dos Poderes políticos a nível federal, em que pese às garantias conferidas a seus membros. Assim, não surpreende que alguns estudiosos tenham observado que essas tenderiam a emprestar uma interpretação expansiva às disposições constitucionais que conferem poderes à União, expandindo sua esfera de competências, e seriam mais propensas a declarar inconstitucionais leis estaduais do que leis federais. A visão convencional do federalismo estadunidense enfatiza o papel desempenhado pela Suprema Corte, ressaltando que essa teria sido crucial para a expansão da competência da União, porém alguns autores contestam sua real relevância para esse processo, argumentando que o que importa, em última análise, seria o sistema de partidos políticos. Estudos comparados recentes sobre Supremas Cortes em Estados federais apontam que, embora a maioria dessas tenha desenvolvido uma tendência centralizadora, algumas se mostraram inclinadas a uma abordagem mais equilibrada, enquanto outras manifestaram diferentes tendências em diferentes momentos. Mas qual é o efeito, afinal, das Supremas Cortes em Estados federais e o que explica a variação nos resultados? Esse debate parece um tanto distorcido pelo fato de que alguns estudiosos que adotam uma perspectiva normativa supõem que federalismo signifique descentralização, ao passo que outros com uma preocupação descritiva argumentam que esse, na realidade, promoveria centralização. Esse trabalho compartilha a suposição de alguns pesquisadores de que esses processos não podem ser explicados pela adoção por si só dessa ou daquela forma de Estado, mas são o resultado de diferentes fatores - incluindo as técnicas de repartição de competências, o grau de rigidez constitucional e o papel desempenhado pela Suprema Corte - e do modo como esses são combinados e interagem entre si. A Assembleia Constituinte brasileira foi convocada em um contexto de transição de um regime autoritário centralizado, o que parece explicar porque os Constituintes pareciam supor que federalismo significasse descentralização, porém alguns autores sustentam que seria incorreto concluir que eles tenham efetivamente adotado uma Constituição descentralizadora, haja vista as competências conferidas à União. O presente trabalho visa a demonstrar que, embora eles tenham previsto uma lista de competências concorrentes, em relação às quais a União deveria limitar-se a editar normas gerais, não definiram o que essas vinham a ser. Na prática, o Congresso edita leis tão detalhadas nessas matérias que deixa pouco espaço para suplementação dos Estados, mas só em raras ocasiões o STF as declarou inconstitucionais por extrapolarem da competência da União. Recentemente, os membros da Corte expressaram unanimemente preocupação com a tendência centralizadora da jurisprudência da Corte sobre federalismo e tentaram conceber princípios para contê-la.

Palavras-chave: federalismo; repartição de competências; Jurisdição Constitucional; centralização. 


\begin{abstract}
BASTOS, Fernando Bertoletti. Federation and Judicial Review. 296 pages. 2020. Thesis (Doctorate). Faculty of Law, University of São Paulo, São Paulo, 2020.

Given that, with very few exceptions, Supreme Courts in federal countries are given the authority to settle disputes concerning the boundaries between the jurisdictions of the general government and of the constituent units, they are generally portrayed as the "arbiters of federalism" which implies that they should be impartial towards both parties and disinterested in the outcome of the case at hand. However, since their Justices are usually appointed through a process involving both the Executive and the Legislative, most Supreme Courts cannot be considered completely independent from the political branches at the federal level, regardless the guarantees their members might have. Thus it is no surprise that some scholars have contended that they tend to confer a broad interpretation to the constitutional provisions that give powers to the general government expanding its jurisdiction and are more prone to uphold federal statutes and to overrule state ones, when these are challenged on constitutional grounds. The conventional view on American federalism emphasizes the crucial role performed by the Supreme Court to the augmentation of powers of the general government, but some scholars have objected the relevance of the Court in this process, saying that it is ultimately the system of political parties that really matters. Recent comparative studies on Supreme Courts in federal countries also indicate that, although most of them have developed a centralizing trend, some have leaned towards a more balanced approach, while others have manifested different tendencies at different times. So, what is the actual effect of Supreme Courts in federal countries and what accounts for the variance in the results? This debate seems somehow distorted by the fact that some scholars that adopt a normative perspective assume that federalism means decentralization, while others with a descriptive concern argue that it actually fosters centralization. This work shares the assumption of some researchers that these processes cannot be explained by the adoption of the form of government itself, but rather are the result of different factors, including the techniques adopted to divide power, the degree of constitutional rigidity and the role performed by the Supreme Court, and the way in which these factors are combined and interact with each other. Brazilian Constituent Assembly has been called in a context of transition from an authoritarian centralized regime, which might explain why the Framers seemed to assume that federalism meant decentralization, but some scholars argue that it is a mistake to suppose that they have really adopted a decentralizing Constitution. This work aims to demonstrate that, although they included a new list of concurrent powers, in which the general government shall only enact framework legislation, they did not define what that meant. In practice, the general government enacts such detailed legislation in those matters, that leave little room for the constituent units to regulate, but the Supreme Court has only rarely overruled this kind of statutes. Recently, the Justices unanimously expressed concern with the centralizing trend of the Court's jurisprudence on federalism and attempted to devise principles to restrain it.
\end{abstract}

Keywords: federalism; division of powers; judicial review; centralization. 


\section{RÉSUMÉ}

BASTOS, Fernando Bertoletti. État fédéral et Justice constitutionnelle. 296 pages. 2020. Thèse (Doctorat). Faculté de Droit, Université de São Paulo, São Paulo, 2020.

Étant donné que, sauf rares exceptions, les Cours Suprêmes des pays fédéraux ont l'autorité de régler les différends concernant les frontières entre les juridictions de l'Union et des États, elles sont généralement décrites comme les «arbitres du fédéralisme» ce qui implique qu'elles doivent être impartiales envers les deux parties et désintéressés de l'issue de l'affaire en cause. Cependant, comme leurs juges sont généralement nommés par un processus impliquant à la fois l'Exécutif et le Législatif, la plupart des Cours Suprêmes ne peuvent pas être considérées comme totalement indépendantes des Pouvoirs politiques au niveau fédéral, malgré les garanties de leurs membres. Il n'est pas étonnant que certains érudits aient affirmé qu'elles ont tendance à conférer une interprétation extensive à des dispositions constitutionnelles qui donnent des pouvoirs à l'Union élargissant sa compétence et sont plus disposés à préserver des lois fédérales et à réviser des lois régionales. Le point de vue conventionnel sur le fédéralisme américain souligne le rôle déterminant joué par la Cour Suprême pour l'augmentation des pouvoirs de l'Union, mais certains érudits ont objecté l'importance réelle de la Cour en disant que c'est en définitive le système de partis politiques qui compte. Des études comparatives récentes sur les Cours Suprêmes des pays fédéraux indiquent également que, bien que la plupart d'entre eux aient développé une tendance centralisatrice, certains ont été enclins à une approche plus équilibrée et d'autres ont manifesté différentes tendances à des moments différents. Quel est l'effet réel des Cours Suprêmes dans les pays fédéraux et qu'est-ce qui explique la variation concernant les résultats? Ce débat semble en quelque sorte déformé parce que les érudits qui adoptent une perspective normative supposent que le fédéralisme signifie décentralisation, tandis que d'autres avec une préoccupation descriptive affirment qu'il favorise la centralisation. Ce travail partage la supposition de certains chercheurs que ces processus ne peuvent pas être expliqués par l'adoption de la forme de l'État elle-même, ils sont plutôt le résultat de nombreux facteurs différents, y compris les techniques adoptées pour diviser les compétences, le degré de rigidité constitutionnelle et le rôle de la Cour Suprême. L'Assemblée Constituante brésilienne a été convoqué dans un contexte de transition d'un régime autoritaire centralisé, ce qui pourrait expliquer pourquoi ses membres semblaient supposer que le fédéralisme signifiait décentralisation, mais certains chercheurs affirment qu'il est faux de supposer qu'ils ont vraiment adopté une Constitution décentralisatrice, compte tenu des compétences conférées à l'Union. Ce travail vise à demontrer que, bien qu'ils y aient inclus une nouvelle liste des compétences concurrentes, dans lesquelles l'Union ne peut adopter que la législation-cadre, ils n'ont pas défini ce que cela signifiait. Dans la pratique, cependant, l'Union adopte une législation si détaillée en ce qui concerne ces questions, qu'elle laisse peu de place pour les réglementations des États, mais la Cour Suprême a rarement infirmé ce genre de lois. Récemment, les juges ont exprimé à l'unanimité leur inquiétude face à la tendance centralisatrice de la jurisprudence de la Cour sur le fédéralisme et ont tenté de concevoir des principes pour la modérer.

Mots clés: fédéralisme; division des pouvoirs; contrôle de constitutionnalité; centralisation. 


\section{LISTA DE ABREVIATURAS E SIGLAS}

$\S$

$\mathrm{AC}$

$\mathrm{ACO}$

ADC

ADI

ADPF

AGU

ANC

Art.

$\mathrm{c} / \mathrm{c}$

$\mathrm{CN}$

CNJ

$\mathrm{CPC}$

$\mathrm{CR}$

DJ

DJe

DOU

EC

EUA

Inc.

LC

LO

$\mathrm{MC}$

Min.

MP

$\mathrm{MPV}$

MS

$\mathrm{OAB}$

PEC

PGR

QO

RAI
Parágrafo

Ação Cautelar

Ação Cível Originária

Ação Declaratória de Constitucionalidade

Ação Direta de Inconstitucionalidade

Arguição de Descumprimento de Preceito Fundamental

Advocacia-Geral da União

Assembleia Nacional Constituinte

Artigo

Combinado

Congresso Nacional

Conselho Nacional de Justiça

Código de Processo Civil

Constituição da República

Diário da Justiça

Diário da Justiça eletrônico

Diário Oficial da União

Emenda Constitucional

Estados Unidos da América

Inciso

Lei Complementar

Lei Ordinária

Medida Cautelar

Ministro

Ministério Público

Medida Provisória

Mandado de Segurança

Ordem dos Advogados do Brasil

Proposta de Emenda Constitucional

Procuradoria-Geral da República

Questão de Ordem

Regional Authority Index 


$\begin{array}{ll}\text { Rcl } & \text { Reclamação } \\ \text { RE } & \text { Recurso Extraordinário } \\ \text { Rel. } & \text { Relator } \\ \text { REsp } & \text { Recurso Especial } \\ \text { RG } & \text { Repercussão Geral } \\ \text { Rp. } & \text { Representação } \\ \text { STF } & \text { Supremo Tribunal Federal } \\ \text { STJ } & \text { Superior Tribunal de Justiça } \\ \text { SV } & \text { Súmula Vinculante } \\ \text { TFUE } & \text { Tratado de Funcionamento da União Europeia } \\ \text { TJ } & \text { Tribunal de Justiça } \\ \text { TUE } & \text { Tratado da União Europeia } \\ \text { UE } & \text { União Europeia } \\ \text { URSS } & \text { União das Repúblicas Socialistas Soviéticas }\end{array}$




\section{SUMÁRIO}

Introdução (originalidade, método, objeto, recorte e plano de trabalho)

1 Noções preliminares para se analisar as relações entre Estado federal e Jurisdição

Constitucional

1.1 Do conceito de federalismo e da (ir)relevância da distinção binária entre Estados federais e unitários

1.2 Fatores relevantes para a (des)centralização em Estados federais e da importância relativa da Jurisdição Constitucional

1.3 Lições dos EUA sobre o papel e a relevância da Suprema Corte na definição dos rumos do federalismo.

$2 \mathrm{O}$ Estado Federal na Constituição brasileira vigente

2.1 Os modelos de Estado federal e do sistema de repartição de competências nos (Ante)projetos da ANC (1987-1988).

2.2 O modelo de Estado federal e o sistema de repartição de competências adotados na Constituição vigente

2.3 Por um conceito positivo e um teste rigoroso de "normas gerais" (para além das "lacunas preenchíveis")

$3 \mathrm{O}$ controle de constitucionalidade e as normas gerais

3.1 Do controle de "legitimidade" da atividade legislativa dos entes federativos (ou do chamado juízo de inconstitucionalidade orgânica).....

3.2 A definição de normas gerais (e suplementares), a interpretação dos parágrafos do artigo 24 e as técnicas de decisão adotadas nessa temática .

4 A "nova" jurisprudência do STF sobre federalismo

4.1 Superação da orientação da corte ("overruling"?) em matéria federativa (o voto do Min. Luiz Fux na ADI No 4.060/SC).

4.2 Proposta de reconhecimento (ou incorporação?) do princípio da subsidiariedade (o voto vencido do Min. Edson Fachin no RE n ${ }^{\circ}$ 194.704/MG).

4.3 A proibição do amianto crisotila por entes subnacionais: um caso de "uncooperative federalism"? (as ADIs no 4.066/DF, 3.937/SP, 3.406/RJ, 3.470/RJ, 3.357/RS, 3.356/PE e

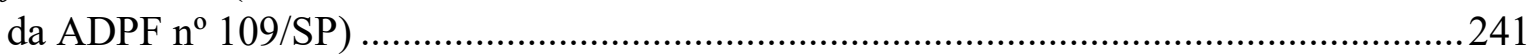

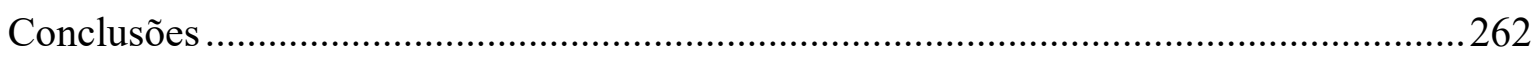

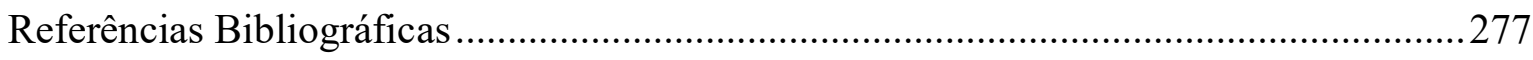




\section{INTRODUÇÃO (ORIGINALIDADE, MÉTODO, OBJETO, RECORTE E PLANO DE TRABALHO)}

Como se sabe, a especialização da produção acadêmica é tanta que torna praticamente sem sentido qualquer tentativa de se procurar um tema em relação ao qual nenhum autor tenha antes se debruçado. Tanto isso é assim que, caso essa busca por um assunto inédito se mostrasse exitosa, provavelmente o seria porque o tema efetivamente encontrado careceria de maior importância. Supõe-se que temas relevantes, precisamente por serem relevantes, já tenham despertado a curiosidade de outros pesquisadores, cujos trabalhos servem de ponto de partida para novos estudos sobre o mesmo tema. Esses são, na realidade, bem-vindos, na medida em que contribuem para compreender melhor seu objeto, observando-o sob outras perspectivas, acrescentando variáveis, ajustando eventuais falhas. É assim, aliás, que avança o conhecimento científico. Não é esse, evidentemente, o primeiro trabalho - e espera-se que tampouco seja o último - a tratar das relações entre Estado federal e Jurisdição Constitucional. Mas é preciso observar, no entanto, que a originalidade de um trabalho acadêmico reside em sua abordagem e não no ineditismo de seu objeto. Embora livre, a escolha do objeto de pesquisa e da forma de abordá-lo revela muito sobre o próprio pesquisador: suas percepções, suas inquietações, seu modo de pensar, sua trajetória. Desde que as premissas sejam adotadas de forma consciente e independente pelo pesquisador, a investigação naturalmente o conduzirá a suas próprias conclusões, que não precisam ser necessariamente inéditas, afinal podem confirmar, por outro caminho, conclusões que já haviam sido sustentadas por outros autores. Ainda com relação à originalidade, é preciso não perder de vista que, como a humanidade se defronta repetidas vezes com as mesmas questões, boa parte dos argumentos já foram levantados. As citações na epígrafe deste trabalho são evidências do que se acaba de dizer: os argumentos centrais do debate sobre as relações entre Estado federal e Jurisdição Constitucional são tão antigos quanto a sua criação.

Pois bem, o presente trabalho vem na sequência de pesquisas anteriores deste autor que se ocuparam de analisar em que medida o Estado brasileiro preencheu, ao longo de sua história, os requisitos de um Estado federal. Sempre lhe impressionou o caráter nitidamente centralizador da estrutura do Estado federal brasileiro resultante das cláusulas de repartição de competências previstas na Constituição. O fato de que, nesse país, grande parte das decisões relevantes estejam concentradas, por definição constitucional, nas mãos da União parece reduzir os Estados a um papel relativamente insignificante no Estado federal brasileiro. A despeito da intenção dos Constituintes de viabilizar uma "descentralização federativa 
gradual”, a verdade é que a Constituição brasileira vigente ${ }^{4}$ não mudou profundamente esse quadro: as listas de competência da União só fizeram aumentar e a esperança de que a descentralização viesse pelo compartilhamento de competências entre os entes federativos não se confirmou. O modelo de competências legislativas concorrentes escolhido pelos Constituintes, pelo qual a União deveria se limitar a editar normas gerais, não se revelou capaz de conter a edição por essa de normas praticamente exaustivas. Isso somado à postura complacente do STF para com essa prática, criou um sistema legal altamente centralizado.

Quando o Min. Francisco Resek queixou-se, ainda sob a vigência da EC nº 01/1969, que na prática consagrava um Estado unitário, que o Poder Judiciário teria se mantido inerte ante o processo de centralização que ameaçava o federalismo brasileiro, essa declaração não era de causar muita surpresa ${ }^{5}$. Todavia, quando, passadas décadas desde a promulgação da Constituição de 1988, que teria "restaurado" a Federação no país ${ }^{6}$, o Min. Luiz Fux fez um comentário semelhante, apontando a própria Corte, ao lado da Constituição, como causas da centralização do federalismo brasileiro ${ }^{7}$, esse parece ser um indicativo muito forte de que é preciso avaliar o efeito da atuação do STF sobre o perfil do Estado federal brasileiro. Afinal, não deixa de ser notável que dois Ministros de épocas diferentes da mesma Corte, com base em Constituições distintas, tenham ambos atribuído a essa alguma responsabilidade pelo processo de centralização do país. Se for verdadeiro que, em que pese à mudança de sistema político e de Constituição, houve continuidade entre os períodos no que diz respeito à centralização, não seria nada disparatado questionar se essa não seria, na realidade, um efeito

\footnotetext{
${ }^{4}$ Convencido pelas considerações por Egon Bockmann MOREIRA, preferiu-se, no presente trabalho, adotar a expressão "Constituição vigente" à "Constituição de 1988"; exceto quando, por uma questão de clareza, haja necessidade de cotejá-la com outras Constituições da história brasileira. Assim: "Por isso que a batizar de 'Constituição de 1988' implica, por um lado, o culto ao passado e, por outro, a expectativa de que surja uma nova. Ainda que inconscientemente, fixar a data de 1988 importa reviver o que se dava no passado brasileiro: a periodicidade de várias Constituições, promulgadas, suspensas ou outorgadas de tempos em tempos (1824; 1891; Revolução de 1930; 1934; 1937; 1946; 1964; 1967; 1969). A fixação de uma cronologia perversa, que celebra o passado e se esquece do futuro. Talvez seja o caso de nos conscientizarmos de que a nossa Constituição não é a de 1988, mas sim a atual - que se renovará, formal e materialmente, no porvir." MOREIRA, Egon Bockmann. Os 29 anos da Constituição que não é a de 1988. Gazeta do Povo. Curitiba, 10 out. 2017. Disponível em: < http://www.gazetadopovo.com.br/justica/colunistas/egon-bockmann-moreira/os29-anos-da-constituicao-que-nao-e-a-de-1988-dg3pxpk2482z6dferlmluhlrt > Data do acesso: 14/10/2017.

5 “Durante mais de meio século [sic] a absorção progressiva, pelo poder central, da competência para compor o ordenamento jurídico, teve curso seguro, sem que o Poder Judiciário se animasse a conter esse processo de que resultaram minadas as bases da federação." BRASIL. Supremo Tribunal Federal (STF). Representação de Inconstitucionalidade (Rp) $n^{\circ}$ 1153/RS. Voto-vista Min. Francisco Resek. Brasília, 10 out. 1984. pp. 173-174.

${ }^{6}$ Discurso Ulysses Guimarães. BRASIL. Assembleia Nacional Constituinte. Diário da Assembleia Nacional Constituinte. Brasília, 5 out. 1988, ano II, n. 308, p. 14380.

7 "[...] a federação brasileira ainda se revela altamente centralizada, muitas vezes beirando o federalismo meramente nominal. Vislumbro dois fatores essenciais para esse quadro. O primeiro é de índole jurídicopositiva [...]. O segundo fator é de natureza jurisprudencial. Não se pode ignorar a contundente atuação do Supremo Tribunal Federal [...]" BRASIL. Supremo Tribunal Federal (STF). Ação Direta de Inconstitucionalidade (ADI) $n^{\circ}$ 4060/SC. Voto Min. Luiz Fux. Brasília, 25 fev. 2015, pp. 7-8.
} 
da atuação da Corte e não de outros fatores. Supõe-se aqui que, embora a atuação da Corte possa sim repercutir sobre a centralização, essa é somente um fator dentre tantos outros que explicam o processo de centralização. Mas como analisar efetivamente o efeito centralizador da atuação do STF?

Em um levantamento realizado pelo Núcleo de Pesquisa "Direito e Política" (DIRPOL) do Programa de Pós-Graduação em Direito da UFPR, constatou-se que: de um total de 4.751 (100\%) ADIs que foram ajuizadas após a promulgação da Constituição de 1988 a agosto de 2012, 1.712 (36\%) tiveram por objeto lei ou ato normativo federal; 2.991 (63\%) tiveram por objeto lei ou ato normativo estadual; e somente $48(2 \%)$ tiveram por objeto lei ou ato normativo municipal. Das primeiras, somente 200 (11\%) foram julgadas favoravelmente ao autor ${ }^{8}$, no sentido da inconstitucionalidade da lei ou ato normativo federal questionado; das segundas, 1.067 (36\%) foram julgadas favoravelmente ao autor, no sentido da inconstitucionalidade da lei ou ato normativo estadual questionado; das últimas, dado o não cabimento de ADI para questionar lei municipal, nenhuma chegou a ser conhecida ${ }^{9}$. Constatou-se, ainda, que uma em cada três decisões legislativas estaduais questionadas perante o STF foram por esse revertidas, ao passo que somente uma em cada quatorze federais tiveram o mesmo resultado, o que indicaria uma probabilidade quase cinco vezes maior de o STF reverter uma decisão legislativa estadual do que uma decisão legislativa federal ${ }^{10}$.

Fabrício TOMIO e Ilton ROBL FILHO procuraram interpretar esses achados, à luz da teoria desenvolvida por George TSEBELIS, segundo a qual um ator com poder de veto seria aquele cuja concordância seria necessária para promover uma mudança no status quo ${ }^{11}$. Assim, quanto mais atores com poder de veto houver, em um determinado processo decisório, e quanto mais díspares forem as suas preferências, mais estável esse será. Por julgar favoravelmente ao autor mais ADIs que tenham por objeto leis ou atos normativos estaduais do que federais

\footnotetext{
${ }^{8}$ Assim entendidas as decisões de procedência, parcial procedência, concessivas de liminar ou parcialmente concessivas de liminar.

9 TOMIO, Fabricio Ricardo de Limas; ROBL FILHO, Ilton Norberto. Empirical Legal Research: teoria e metodologia para a abordagem do processo decisório de controle de constitucionalidade no STF. In: VESTENA, Carolina Alves; SIQUEIRA, Gustavo Silveira. Direito e experiências jurídicas. Vol. II: debates práticos. Belo Horizonte: Arraes Editores, 2013, p. 109.

${ }_{10}$ TOMIO, Fabricio Ricardo de Limas; ROBL FILHO, Ilton Norberto. Empirical Legal Research: teoria e metodologia para a abordagem do processo decisório de controle de constitucionalidade no STF. In: VESTENA, Carolina Alves; SIQUEIRA, Gustavo Silveira. Direito e experiências jurídicas. Vol. II: debates práticos. Belo Horizonte: Arraes Editores, 2013, p. 112.

11 TSEBELLIS, George. Veto players and institutional analysis. Governance: an International Journal of Policy and Administration, v. 13, n. 4, out. 2000, p. 442.
} 
(não só numericamente, como também proporcionalmente), eles concluem que “[...] $o$ STF é um ator institucional (com poder de veto) muito mais presente no processo decisório estadual, portanto suas decisões aumentam a estabilidade decisória dos conflitos internos aos Estados e entre os Estados (federativos)." 12 Isto é, os resultados confirmariam, de um lado, a hipótese de que o STF atuaria como um ator com poder de veto em relação ao processo decisório estadual e, de outro, a de que esse seria absorvido pelos demais atores em relação ao processo decisório federal.

Do ponto de vista dos legitimados para propor ADIs perante o STF, constatou-se que o PGR foi o que o teve a maior taxa de sucesso tanto em relação ao processo decisório federal (23\%) como estadual (de quase 40\%). Em relação ao processo decisório estadual, destacaram-se ainda os governadores (também com uma taxa de quase 40\% de sucesso), não só com relação ao processo decisório do próprio Estado, como ao de outros Estados. Segundo os autores, os dispositivos constitucionais mais invocados por esses últimos, em suas ADIs, seriam os referentes às competências privativas do chefe do Poder Executivo e às da União (arts. 61, $\S 1^{\circ}$, e $22, \mathrm{CR}$, respectivamente) ${ }^{13}$. As confederações sindicais ou entidades de classe de âmbito nacional, embora tenham sido os legitimados que mais propuseram ADIs em relação ao processo decisório federal, teriam baixas taxas de sucesso, assim como os partidos políticos que, segundo os autores, se valeriam dessas ações mais para dar uma satisfação a seu eleitorado e para impor custos políticos ao governo.

Diante disso, os autores concluem que os achados da pesquisa corroborariam a hipótese de que a expansão, pela Constituição vigente, do número de legitimados para propor ADIs perante o STF, não mais restrita ao PGR, teria gerado efeitos distintos em relação aos processos decisórios estaduais e federal: de um lado, “[...] as ADIs aumentam a estabilidade decisória estadual, seja limitando as decisões legislativas de maiorias oposicionistas (por judicialização iniciada pelos governadores), seja restringindo decisões de coalizões majoritárias estaduais (governadores e Procurador-Geral)" ${ }^{14}$, de outro, "[...] a judicialização

${ }^{12}$ TOMIO, Fabricio Ricardo de Limas; ROBL FILHO, Ilton Norberto. Empirical Legal Research: teoria e metodologia para a abordagem do processo decisório de controle de constitucionalidade no STF. In: VESTENA, Carolina Alves; SIQUEIRA, Gustavo Silveira. Direito e experiencias jurídicas. Vol. II: debates práticos. Belo Horizonte: Arraes Editores, 2013, p. 110.

${ }^{13}$ TOMIO, Fabricio Ricardo de Limas; ROBL FILHO, Ilton Norberto. Empirical Legal Research: teoria e metodologia para a abordagem do processo decisório de controle de constitucionalidade no STF. In: VESTENA, Carolina Alves; SIQUEIRA, Gustavo Silveira. Direito e experiencias jurídicas. Vol. II: debates práticos. Belo Horizonte: Arraes Editores, 2013, p. 114.

${ }_{14}^{14}$ TOMIO, Fabricio Ricardo de Limas; ROBL FILHO, Ilton Norberto. Empirical Legal Research: teoria e metodologia para a abordagem do processo decisório de controle de constitucionalidade no STF. In: 
no nível federal tem mais um caráter de sinalização de posicionamento político por minorias legislativas e tentativas infrutiferas de grupos de interesse em evitar legislação, causando pouco efeito sobre o poder de agenda do governo e das coalizações majoritárias."15

Comentando os resultados dessa pesquisa, Fabrício TOMIO, Ilton ROBL FILHO e Rodrigo KANAYAMA observam, em outro trabalho, que "[o] principal resultado dessa pesquisa empírica apontou que, de um lado, essas ações produzem a centralização do poder normativo na União e, de outro lado, há pequena quantidade de ADIs exitosas na proteção e promoção dos direitos fundamentais." 16 E explicam que "Essa centralização ocorre em razão da razoável taxa de declaração de atos normativos estaduais pelo STF e pela pequena quantidade de reconhecimento de inconstitucionalidades dos atos federais/nacionais [...]." ${ }^{\prime 17}$ Ainda que os achados levantados pelo DIRPOL no que diz respeito à disparidade entre o índice de procedência das ADIs que tinham por objeto leis estaduais, de um lado, e leis federais, de outro, bem como a análise realizada por TOMIO e ROBL FILHO acerca do papel desempenhado pelo STF como um ator com poder de veto em relação ao processo legislativo estadual e de sua absorção pelos demais atores a nível federal, sejam indiscutivelmente relevantes, entende-se aqui que não se pode dizer que os resultados da pesquisa tenham confirmado a hipótese de que as decisões proferidas pelo STF em sede de controle abstrato de constitucionalidade promoveriam a centralização do Estado federal brasileiro.

Por mais legítima e razoável - e possivelmente até correta - que essa hipótese possa parecer, não poderia ser confirmada com base nas métricas adotadas pela pesquisa: a mera comparação entre o número de ADIs julgadas procedentes que tinham por objeto leis estaduais, de um lado, e leis federais, de outro. Tais números, o máximo que fazem, é contar decisões, não se prestam a medir a centralização ou descentralização do Estado.

\footnotetext{
VESTENA, Carolina Alves; SIQUEIRA, Gustavo Silveira. Direito e experiências jurídicas. Vol. II: debates práticos. Belo Horizonte: Arraes Editores, 2013, pp. 112-113.

15 TOMIO, Fabricio Ricardo de Limas; ROBL FILHO, Ilton Norberto. Empirical Legal Research: teoria e metodologia para a abordagem do processo decisório de controle de constitucionalidade no STF. In: VESTENA, Carolina Alves; SIQUEIRA, Gustavo Silveira. Direito e experiências jurídicas. Vol. II: debates práticos. Belo Horizonte: Arraes Editores, 2013, p. 112.

16 TOMIO, Fabricio Ricardo de Limas; ROBL FILHO, Ilton Norberto; KANAYAMA, Rodrigo Luis. Constitucionalismo estadual e controle abstrato e concentrado de constitucionalidade nos Tribunais de Justiça: efeitos das ações diretas de inconstitucionalidade (ADI) estaduais na Federação brasileira. Revista de Direito brasileira, ano 5, v. 12, 2015, pp. 89-90. Grifos deste autor.

17 TOMIO, Fabricio Ricardo de Limas; ROBL FILHO, Ilton Norberto; KANAYAMA, Rodrigo Luis. Constitucionalismo estadual e controle abstrato e concentrado de constitucionalidade nos Tribunais de Justiça: efeitos das ações diretas de inconstitucionalidade (ADI) estaduais na Federação brasileira. Revista de Direito brasileira, ano 5, v. 12, 2015, p. 90. Grifos deste autor.
} 
Ressalte-se que, no Brasil, enquanto há 27 entes federativos que desempenham competências estaduais (os 26 Estados +o Distrito Federal), há somente um que desempenha competências federais (a União); ou, reformulando nos termos da pesquisa de TOMIO e ROBL FILHO, enquanto há 27 processos decisórios estaduais, há somente um federal. Portanto, a razão entre esses processos decisórios é de 27 para 1 (27:1), o que parece relativizar a importância do achado de que 2/3 da pauta do STF com ADIs é ocupada com o controle de leis estaduais e somente 1/3 com o de leis federais. Com essa desproporção numérica, para compará-los seria preciso, no mínimo, introduzir filtros para controlar seus resultados, haja vista que é perfeitamente possível que diferentes Estados, que detêm as mesmas competências, editem leis semelhantes e que essas sejam questionadas perante o STF em diferentes ADIs, o que, sem a introdução de filtros, seria computado mais de uma vez ${ }^{18}$.

Não se pode deixar de observar, ainda, que as esferas de competência da União e dos Estados são muito díspares, tanto do ponto de vista quantitativo, como do ponto de vista qualitativo. Para se chegar a essa conclusão, basta fazer uma simples leitura do articulado da Constituição vigente, particularmente dos artigos 21 a 25: chama atenção a extensão e o detalhamento do catálogo de competências exclusivas e privativas da União (arts. 21-22, CR), sem falar na sua competência para editar normas gerais nas matérias de competência concorrente (art. 24, $\S 1^{\circ}, \mathrm{CR}$ ), enquanto que aos Estados são relegadas competências meramente residuais (art. $25, \S 1^{\circ}$ ), algumas competências enumeradas (arts. 18, $\S 4^{\circ}$, e $\left.25, \S \S 2^{\circ}-3^{\circ}, C R\right)$, bem como a competência suplementar nas matérias de competência concorrente (art. 24, $\S 2^{\circ}, \mathrm{CR}$ ). Sendo assim, como comparar, com base em números, 27 processos decisórios estaduais incidentes sobre uma área reduzida de competência com 1 processo decisório federal sobre uma área extensa de competência? Isso é ainda mais desafiador levando-se em consideração a importância relativa dessas matérias: como quantificar, por exemplo, a competência privativa da União para legislar sobre Direito Civil

\footnotetext{
${ }^{18}$ Exemplo disso são as ADIs no 3847/SC, 4478/AP, 3343/DF e 2615/SC, todas propostas pelos governadores dos respectivos Estados (exceto a $\mathrm{ADI} \mathrm{n}^{\circ}$ 4478/AP, que foi proposta por uma entidade de classe de âmbito nacional), questionando a constitucionalidade de leis estaduais e distrital que, em síntese, proibiam a cobrança de assinatura básica em serviços de telefonia. Outro exemplo disso são as ADIs n 3835/MS, 5356/MS, 4861/SC e 5253/BA, todas propostas por entidade de classe de âmbito nacional, questionando a constitucionalidade de leis estaduais que determinavam às empresas concessionárias de serviços de telefonia móvel que instalassem equipamentos para interrupção de sinal de celular nas áreas de unidades prisionais no Estado. Todas essas ações foram julgadas procedentes, por maioria, pelo STF. Mais um exemplo são as ADIs no 4954/AC, 4948/RR, 4953/MG, 4949/RJ, 4423/DF, 4955/CE, 4093/SP, 4952/PB e a ADPF 273/MT, todas propostas pelo PGR (exceto a ADI n ${ }^{\circ} 4093 / \mathrm{SP}$, que foi proposta pelo governador do respectivo Estado), questionando a constitucionalidade de leis estaduais, distrital e uma municipal que, em síntese, disciplinam a comercialização de artigos de conveniência por farmácias e drogarias. Dessa vez, todas essas ações foram julgadas improcedentes, por unanimidade, pelo STF.
} 
ou a competência da União para editar normas gerais em Direito Financeiro e a competência correspondente dos Estados, nessas matérias, para suplementá-las?

E mesmo a discrepância entre a probabilidade de o STF vir a declarar inconstitucional uma lei estadual, de um lado, e uma lei federal, de outro, tampouco revela necessariamente um favoritismo ou uma predileção da Corte para com a União ou sua conivência com o processo de centralização do federalismo. Diversos fatores podem desempenhar um papel importante nesse resultado, não se podendo ignorar, por exemplo, a própria qualidade das leis, que não se deve supor seja a mesma para leis federais e estaduais. Um indício disso é o número de ADIs que são propostas por governadores questionando a constitucionalidade de leis do próprio Estado, porque o veto que esses haviam aposto à lei acabou sendo derrubado pela respectiva Assembleia Legislativa, desconsiderando a suposta inconstitucionalidade contida na lei. Além disso, não raro, o STF é provocado para exercer o chamado "controle de qualidade" de leis estaduais completamente inaptas do ponto de vista técnico. Nesse caso, o que a procedência da ADI quer dizer quanto às relações federativas? Se não nada, muito pouco.

Outra questão é que, embora a pesquisa tenha tido a preocupação de levantar todo o universo de ADIs propostas desde a promulgação da Constituição até aquele momento, a verdade é que nem todas as ações são igualmente importantes para a questão da centralização do federalismo brasileiro; algumas, aliás, podem ser completamente irrelevantes. Assim, ao evitar o problema da seleção da amostra, levantado toda a população, deixou-se de distinguir entre o que é e o que não é relevante para o tema. Além disso, embora a decisão de se ater às ADIs seja coerente com a aplicação da teoria dos atores com poder de veto, haja vista que a decisão de procedência nessas ações tem, via de regra, o efeito de extirpar a lei ou ato normativo do ordenamento jurídico (embora, por esse motivo, fosse o caso de incluir também as ADCs e as ADPFs), a limitação do levantamento acabou criando uma espécie de amostra, ao menos quanto à pretensão da pesquisa de oferecer respostas para a centralização do federalismo brasileiro. Afinal, não há motivos para se supor que apenas as ADIs ou as ações do controle abstrato de constitucionalidade repercutiriam sobre o perfil do Estado federal brasileiro. As decisões do controle concreto de constitucionalidade também são importantes, especialmente em se levando em consideração a competência do STF prevista no art. 102, I, “ $f$ ” da Constituição vigente, para arbitrar conflitos entre entes federativos. Mas é preciso reconhecer que inclusive as decisões tomadas pela Corte, em sede de recurso extraordinário, com fundamento no art. 102, III, da Constituição vigente, formam precedentes 
para decisões futuras em casos semelhantes. Assim, não parece haver motivos para se ater ao controle abstrato de constitucionalidade, ao menos no que se refere à pretensão de oferecer explicações para a centralização.

Tampouco se pode dizer que esses autores tenham efetivamente testado a hipótese de "[...] se há uma maior probabilidade de o STF vetar uma legislação estadual (esfera estadual/federativa) do que uma legislação federal (União), em função da distribuição de competências legislativas no federalismo brasileiro"19. É que nem todas as ADIs propostas perante o STF questionam a constitucionalidade de leis ou atos normativos com base em vício de inconstitucionalidade orgânica, ou seja, aquele que decorre do descumprimento das cláusulas de repartição de competências (umas questionam somente vícios materiais; outras, vícios estritamente formais), o que significa dizer que somente uma parte das ADIs analisadas foi proposta nestes termos, porém o estudo não diferencia entre umas e outras. É verdade que esse distingue as ações com base em diversos critérios: o resultado de seu julgamento (procedência, total ou parcial, ou improcedência ou, ainda, não conhecimento da ação); a procedência (federal, estadual e municipal) e a espécie (Constituição, lei, MPv e outros) de seu objeto e o legitimado que a propôs (PGR, governadores, associações, partidos políticos, OAB etc.). Acredita-se, inclusive, que os autores conheçam esses dados, pois indicaram os dispositivos constitucionais mais comumente suscitados pelos governadores em suas ADIs, porém a verdade é que esses não constam expressamente no estudo.

Como não há, nos dados e nas tabelas apresentadas nesses trabalhos, especificação do dispositivo constitucional invocado como parâmetro para declarar inconstitucionais leis e atos normativos questionados, ao que tudo indica ${ }^{20}$, os autores parecem presumi-lo com base no propositor da ação. É preciso observar, no entanto, que nada obsta, por exemplo, que confederações sindicais ou entidades de classe de âmbito nacional questionem a constitucionalidade de uma lei estadual por usurpação de competência privativa (art. 22, CR)

\footnotetext{
${ }^{19}$ TOMIO, Fabricio Ricardo de Limas; ROBL FILHO, Ilton Norberto. Empirical Legal Research: teoria e metodologia para a abordagem do processo decisório de controle de constitucionalidade no STF. In: VESTENA, Carolina Alves; SIQUEIRA, Gustavo Silveira. Direito e experiências jurídicas. Vol. II: debates práticos. Belo Horizonte: Arraes Editores, 2013, p. 107.

${ }^{20}$ É o que sugere a seguinte passagem do trabalho: "[...] essa possibilidade é tratada pelas hipóteses secundárias, que introduzem a participação dos legitimados na judicialização. As Hipóteses 3 e 4 são derivadas diretamente desses mecanismos constitucionais. Ou seja, procuramos verificar se há uma maior probabilidade de o STF vetar uma legislação estadual (esfera estadualffederativa) do que uma legislação federal (União), em função da distribuição de competências legislativas no federalismo brasileiro. Isso é verificado pela Hipótese 4." TOMIO, Fabricio Ricardo de Limas; ROBL FILHO, Ilton Norberto. Empirical Legal Research: teoria e metodologia para a abordagem do processo decisório de controle de constitucionalidade no STF. In: VESTENA, Carolina Alves; SIQUEIRA, Gustavo Silveira. Direito e experiências jurídicas. Vol. II: debates práticos. Belo Horizonte: Arraes Editores, 2013, p. 107.
} 
ou para editar normas gerais ( $\left.\operatorname{art} 24, \S 1^{\circ}, \mathrm{CR}\right)$ da União ou que governadores questionem a constitucionalidade de uma lei federal por violação a direito fundamental. Não parece correto supor, com base somente no propositor da ADI, que a análise da ação tenha envolvido as cláusulas constitucionais de repartição de competências, para daí extrair conclusões a respeito do efeito centralizador ou descentralizador das decisões do STF em relação ao perfil do Estado federal brasileiro. Isso significa que, ao menos no que se refere à questão da centralização, as conclusões dessa pesquisa, também por mais legítimas e razoáveis que possam ser e possivelmente até corretas, carecem de confirmação empírica.

Não há nada de trivial em tais objeções, haja vista que as conclusões dessa pesquisa têm reverberado na doutrina, com se observa do trabalho de Marco MARRAFON e Leonam LIZIERO que, com base nesses e em outros dados coletados das ADIs propostas perante o STF, observam que "[a]lém do STF ter o poder de legislador negativo, pelo que os dados apresentam, há uma significativa interferência no processo legiferante estadual (ainda que em momento posterior), devido à percentagem de ações que são decididas a favor do requerente." 21 E concluem: "[...] a ADI foi largamente usada para fins de reafirmar a centralização causada pela distribuição de competências. [...] Ao intervir como ator de veto nos processo legislativo [sic] com grande participação diretamente no de âmbito estadual, o Supremo Tribunal se torna fiador da concentração de poderes nas mãos do Governo Central." 22 Embora MARRAFON e LIZIERO ressaltem, com maior ênfase, a importância do fator Constituição para a centralização e que a metáfora do STF como "fiador" da centralização no Brasil empregada por esses autores seja interessante, na medida em que as decisões da Corte não promoveriam por si próprias a centralização, não se pode deixar de reconhecer que suas conclusões, ao partirem dos dados levantados por essa pesquisa, incorrem nas mesmas objeções descritas acima.

Não se põe aqui em dúvida que a pesquisa empírica realizada pelo DIRPOL e a análise do papel desempenhado pelo STF como um ator com poder de veto no processo decisório estadual que, com base em seus resultados, fizeram TOMIO e ROBL FILHO

\footnotetext{
${ }^{21}$ MARRAFON, Marco Aurélio; LIZIERO, Leonam Baesso da Silva. Competências da União e Supremo Tribunal Federal: fiadores da centralização no federalismo brasileiro. In: FISCHER, Octavio Campos (Coord.); SANTOS, Scheila Barbosa dos (Org.). Federalismo Fiscal e Democracia. Curitiba: Instituto Memória Editora, 2014, p. 41.

22 MARRAFON, Marco Aurélio; LIZIERO, Leonam Baesso da Silva. Competências da União e Supremo Tribunal Federal: fiadores da centralização no federalismo brasileiro. In: FISCHER, Octavio Campos (Coord.); SANTOS, Scheila Barbosa dos (Org.). Federalismo Fiscal e Democracia. Curitiba: Instituto Memória Editora, 2014 , p. 45.
} 
representam um importante avanço na literatura sobre o tema. Com essa pesquisa, o que antes não passava de uma percepção de observadores (a suspeita de que a Corte, ao exercer o controle de constitucionalidade de leis e atos normativos, tendia a decidir favoravelmente à União e em detrimento dos Estados), passou ter algum respaldo empírico (embora, como se viu, entenda-se aqui que, ao menos no que diz respeito à centralização do federalismo brasileiro, as conclusões do trabalho carecem de suporte empírico). Mas, se não assim, então como avaliar o efeito das decisões do STF sobre o processo de centralização do federalismo brasileiro?

Uma contribuição que as ciências jurídicas podem oferecer ao estudo empírico do efeito das decisões tomadas pelo STF, em sede de controle de constitucionalidade, sobre o perfil do Estado federal brasileiro é identificar qual é a interpretação que a Corte, na qualidade de suprema intérprete da Constituição, empresta às cláusulas de repartição de competências entre os entes federativos, se houve variação de seu entendimento ao longo do tempo e, nesse caso, identificar que fatores foram relevantes para essa mudança. Assim: se uma interpretação expansiva das cláusulas constitucionais que atribuem competência à União significaria centralização, na medida em que legitimaria a atuação do ente central sobre áreas inicialmente não cogitadas, uma interpretação restritiva dessas mesmas cláusulas teria o efeito - não necessariamente contrário, no sentido da descentralização - de, no mínimo, conter esse processo, impondo limites para além dos quais a atuação da União seria ilegítima. Do mesmo modo, se uma interpretação expansiva das cláusulas constitucionais que atribuem competência aos Estados, DF e Municípios significaria descentralização, na medida em que legitimaria a atuação dos entes subnacionais sobre áreas incialmente não previstas, uma interpretação restritiva dessas mesmas cláusulas teria o efeito - não necessariamente contrário, no sentido da centralização - de, pelo menos, conter esse processo, impondo limites para além dos quais a atuação desses tampouco seria legítima. Claro que isso é uma simplificação, mas oferece um modelo de análise que pode ser testado por meio da leitura das decisões da Corte envolvendo as cláusulas constitucionais de repartição de competências.

Tabela 1: efeito das decisões do STF sobre o perfil do Estado federal brasileiro por tipo de interpretação (expansiva/restritiva) e por tipo de cláusula de atribuição de competência (União/Estados) 


\begin{tabular}{|c|c|c|c|}
\hline & \multicolumn{2}{|c|}{ Cláusulas constitucionais de atribuição de competência } \\
\hline & & $\begin{array}{c}\text { União } \\
\left.\text { (i.e. arts. } 22 \text { e } 24, \S \S 1^{\circ} \text { e } 4^{\circ}, C R\right)\end{array}$ & $\begin{array}{c}\text { Estados } \\
\left.\text { (i.e. arts. } 25, \S 1^{\mathrm{o}}, 24, \S \S 2^{\mathrm{o}}-3^{\mathrm{o}}, \mathrm{CR}\right)\end{array}$ \\
\hline \multirow{2}{*}{ 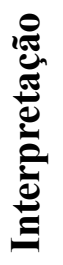 } & Expansiva & Centralização & Descentralização \\
\hline & Restritiva & Contenção da centralização & Contenção da descentralização \\
\hline
\end{tabular}

Com isso, a pesquisa enfoca o controle da chamada inconstitucionalidade orgânica de tipo vertical, ou seja, aquela que se produz quando uma lei ou um ato normativo foi editado com invasão ou usurpação de competência de um ente federativo por outro, ou seja, com desrespeito às cláusulas constitucionais de repartição de competências. Explica-se: para facilitar seu estudo, a doutrina costuma classificar os vícios de inconstitucionalidade em diferentes categorias. As mais conhecidas são a do vício material, aquele que decorre da desconformidade entre o conteúdo da lei ou do ato normativo e o disposto na Constituição, e a do vício formal, aquele que decorre do descumprimento, quando da elaboração e formalização da lei ou ato normativo, do procedimento ou dos requisitos de forma exigidos na Constituição. A inconstitucionalidade orgânica, ora indicada como uma subespécie da categoria de vícios formais, ora como uma categoria à parte situada ao lado das categorias material e formal, decorre da edição da lei ou do ato normativo por sujeito diverso daquele que a tanto foi incumbido pela Constituição. Isso tanto pode ocorrer em nível horizontal, quando o sujeito que editou a lei ou o ato normativo não é especificamente aquele a quem a Constituição confiou essa competência, como vertical, quando a lei ou o ato normativo foi editada por ente federativo diverso daquele a quem a Constituição atribuiu a competência. Como se vê, a inconstitucionalidade orgânica de tipo vertical é um problema genuinamente federativo e, ao enfocar essa categoria ou subespécie de juízo de inconstitucionalidade, dentro do conjunto de decisões tomadas pelo STF no exercício do controle de constitucionalidade, pode-se saber qual é a interpretação que a Corte empresta às cláusulas de repartição de competências e, em última análise, extrair conclusões sobre o efeito de suas decisões sobre o perfil do Estado federal brasileiro.

Não quer isso dizer que os demais tipos de vícios de inconstitucionalidade sejam irrelevantes do ponto de visto federativo; longe disso. Uma lei editada pela União pode 
ter sua constitucionalidade questionada por violar o chamado "princípio federativo", que costuma ser associado ao disposto nos artigos $1^{\circ}$, caput, 18, caput, e $60, \S 4^{\circ}$, I, ou a autonomia dos entes federativos, prevista nos artigos 18, caput, e 25, caput, todos da Constituição vigente. Nesse caso, não obstante o tipo de vício de inconstitucionalidade cogitado seja de natureza material e não orgânica, a questão teria indiscutivelmente relevância federativa. Outro tipo de questão, relevante do ponto de vista federativo, que não diz respeito necessariamente ao vício de inconstitucionalidade orgânica, é o relativo ao chamado "princípio da simetria" ${ }^{23}$ que, ressalte-se, não se encontra previsto expressamente na Constituição vigente. A aplicação desse princípio, de construção jurisprudencial, restringe a autonomia, particularmente na sua dimensão da auto-organização, dos Estados e pode, eventualmente, levar à declaração de inconstitucionalidade de disposições de Constituições estaduais por inobservância do modelo estabelecido para a União na Constituição da República. Marcelo Labanca Corrêa de ARAÚJO entende que, nesse caso, a rigor a disposição da Constituição estadual seria inconstitucional não por violar o princípio da simetria e sim por deixar de observar um princípio extensível presente na Constituição da República ${ }^{24}$. Essas e tantas outras questões são, sem sombra de dúvida, relevantes na definição do perfil do Estado federal, porém o recorte aqui proposto é de atentar apenas e tão-somente para os vícios de inconstitucionalidade orgânica sobre a atividade legislativa dos entes subnacionais e, com isso, avaliar o efeito das decisões do STF sobre o perfil do Estado federal brasileiro.

Para fazer isso, não basta analisar somente alguns aspectos externos, como o propositor e o objeto da ação, e internos, como o resultado do julgamento, das decisões,

\footnotetext{
23 “[...] poder-se-ia construir um conceito do princípio da simetria como um princípio de interpretação da nova hermenêutica constitucional destinado a identificar normas de extensão na Constituição Federal que devem ser necessariamente reproduzidas pelas Constituições estaduais, bem como destinado a identificar as normas das Constituições [sic] Federal que, mesmo não gerando a obrigação de reprodução, geram a imitação facultativa de um modelo federal válido para os estados-membros, funcionando, inclusive, como argumento de exclusão das vedações para reprodução desses mesmos modelos." ARAÚJO, Marcelo Labanca Corrêa de. Jurisdição constitucional e Federação: o princípio da simetria na jurisprudência do STF. Rio de Janeiro: Elsevier, 2009, p. 129.

24 “Em verdade, o princípio da simetria estará sendo entendido como norma se for utilizado como parâmetro para declarar a inconstitucionalidade de uma lei. Por outro lado, estará sendo entendido como um princípio de hermenêutica se for utilizado como meio para buscar uma norma parâmetro dentro do texto constitucional, a fim de identificar a necessidade de extensão, ou não, para avaliar a constitucionalidade ou inconstitucionalidade de lei ou constituição estadual em face do texto constitucional federal." E "Não é um princípio de direito positivo, eis que eventual declaração de invalidade de norma estadual não deve se dar com a alegação de desrespeito ao princípio da simetria, mas sim com a alegação de desrespeito a um modelo normativo federal de organização dos Poderes, com identificação das normas parâmetro violadas. O que o princípio da simetria faz é identificar qual modelo é esse, pelo critério da necessidade de harmonização dos poderes locais." ARAÚJO, Marcelo Labanca Corrêa de. Jurisdição constitucional e Federação: o princípio da simetria na jurisprudência do STF. Rio de Janeiro: Elsevier, 2009, pp. 124 e 130, respectivamente.
} 
tal como feito na pesquisa do DIRPOL, é preciso examinar o próprio conteúdo das decisões, o voto de cada um dos Ministros que participaram do julgamento da ação, na tentativa de identificar quais foram os fundamentos que levaram a Corte a decidir nesse ou naquele sentido. Poder-se-ia objetar que, em se tratando de pesquisa empírica, é preciso dar prevalência a como a Corte de fato decidiu, a como os Ministros efetivamente votaram e não aos argumentos que foram por esses por ventura invocados para justificar seus votos em um ou outro sentido. Afinal, pode ocorrer que um Ministro argumente em um sentido, mas acabe ao final votando em outro, de modo que a análise da fundamentação de seu voto poderia se prestar mais a confundir o pesquisador do que a aclará-lo. Com efeito, como se verá ao longo desse trabalho, não raro Ministros que votam pela inconstitucionalidade da lei estadual, discorrem longamente sobre a importância do federalismo e da descentralização. Sob esse aspecto, o método empregado pela pesquisa do DIRPOL, ao classificar as ADIs conforme o resultado do julgamento, teria a vantagem de avaliar as decisões não pelo que foi dito e sim pelo que foi decidido. É preciso observar, porém, que tal método tampouco aclara possíveis motivos ocultos na retórica dos Ministros, somente os admite, ao passo que a análise da fundamentação pode, pelo menos, revelar algumas pistas sobre quando isso ocorre. Sabe-se, ainda, que a identificação da chamada ratio decidendi (ou seja, das razões para decidir) pode ser especialmente desafiadora em órgãos colegiados que, como o STF, adotam como método deliberativo a convergência no resultado do julgamento, que possibilita que decisões sejam tomadas mesmo quando os Ministros integrantes da maioria tenham votado em um mesmo sentido, porém com base em fundamentos distintos. De todo modo, não parece haver outro modo de se conhecer qual é a interpretação que a Corte empresta às cláusulas constitucionais de repartição de competências senão pela leitura das decisões, na tentativa de identificar os fundamentos que levaram à declaração de inconstitucionalidade, por vício orgânico, de uma determinada lei.

A amostragem reunida no presente trabalho compreende um total de 140 acórdãos do STF (não só do Plenário, como de ambas as suas Turmas), julgados não só em sede de controle abstrato, como de controle concreto de constitucionalidade, desde a promulgação da Constituição vigente e que já estivessem disponíveis para consulta no site do Tribunal até o dia 13/06/2019. Para se chegar a essa amostra, foi utilizada a indexação das decisões feita pela própria Corte, em uma busca pelos $\S \S 1^{\circ}$ e $2^{\circ}$ do art. 24 da Constituição vigente 
$\operatorname{combinados}^{25}$. Com isso, foi possível examinar com maior profundidade esse conjunto de casos que, em relação às ações de controle abstrato de constitucionalidade - cujas peças processuais foram disponibilizadas para consulta no site do Tribunal (em alguns casos, somente a petição inicial) -, abrangeu não só o relatório e os votos dos Ministros (ou seja, o inteiro teor do acórdão), como a petição inicial da ação, as informações prestadas pelas autoridades e órgãos legiferantes e as manifestações da AGU e da PGR. Com isso, almejouse identificar não só a interpretação que a Corte emprestou a esses dispositivos constitucionais, como de que modo essa julga os casos envolvendo vício de inconstitucionalidade orgânica nas matérias de competência concorrente.

Poder-se-ia objetar que valer-se da indexação das decisões pode produzir distorções nos resultados. Afinal, não é nada disparatado supor que as decisões mais antigas da Corte não fossem tão bem indexadas como as decisões mais recentes e que decisões mais relevantes sejam mais bem indexadas que decisões menos relevantes. Com efeito, em se analisando a amostra, verifica-se que: dos 140 acórdãos selecionados, somente 18 foram proferidos nos 10 anos posteriores à promulgação da Constituição vigente, 51 nos 10 anos subsequentes e os 71 restantes nos últimos 11 anos. Também se poderia objetar que algumas decisões importantes ficaram de fora da amostra selecionada, como a ADI n ${ }^{\circ}$ 927/DF, as ADIs $n^{\circ} 252$

\footnotetext{
${ }^{25}$ Utilizou-se a seguinte "expressão de busca" na pesquisa de jurisprudência disponível no site do STF: “CF-1988 MESMO ART-00024 ADJ40 PAR-00001 E CF-1988 MESMO ART-00024 ADJ40 PAR-00002". Dessa busca, obtiveram-se 140 resultados (104 ADIs, 2 ADPFs; 24 REs; 4 AIs; 2 HCs; 1 ACO; 1 AR; 1 MS; 1 Rcl):

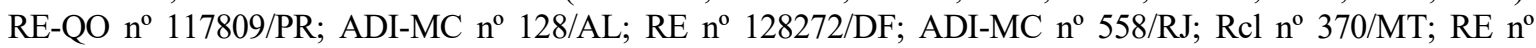
129877/SP; ADI-MC no 861/AP; RE no 149922/SP; ADI-MC n 1045/DF; ADI-MC n 1057/BA; ADI-MC n ${ }^{\circ}$ 1127/DF; RE $n^{\circ}$ 154273/SP; ADI-MC n ${ }^{\circ} 1285 / \mathrm{SP}$; HC no 71702/RS; RE no 193817/RJ; ADI $n^{\circ} 1540 / \mathrm{MS}^{\circ}$ RE $n^{\circ}$ 199720/SP; RE no 198799/DF; ADI-MC no 1926/PE; ADI-MC no 1980/PR; ADI-MC no 2035/RJ; ADI-QO nº 1885/DF; ADI-MC nº 2024/DF; RE nº 241494/DF; RE nº 183907/SP; ADI-MC nº 2124/RO; ADI-QO n ${ }^{\circ} 2344 / \mathrm{SP}$; $\mathrm{ADI}_{\mathrm{MC}} \mathrm{n}^{\circ}$ 2303/RS; AI-AgR n 296935/DF; ADI-MC nº 2123/ES; ADI n 1600/UF; ADI-MC n 2311/MS; ADI$\mathrm{MC} \mathrm{n}^{\circ}$ 2667/DF; AI-AgR no 380695/SP; ADI-MC n 2372/ES; RE no 291188/RN; RE n 158834/SP; RE-ED n ${ }^{\circ}$ 236135/SP; ADI no 2334/DF; ADI no 2396/MS; ADI nº 2656/SP; ADI n 1624/MG; ADI-MC n 1931/DF; ADI no 882/MT; ADI nº 2472/RS; RE-AgR nº 394343/MG; ADI n ${ }^{\circ}$ 1589/SP; AI-AgR nº 403095/SP; ADI n ${ }^{\circ} 3054 / \mathrm{PR}$; ADI $n^{\circ}$ 1245/RS; ACO-QO no 684/MG; ADI no 1007/PE; ADI nº 3098/SP; ADI no 2903/PB; ADI n ${ }^{\circ} 3645 /$ PR; ADI ${ }^{\circ}$ 2591/DF; ADI n 3710/GO; RE-QO no 430105/RJ; ADI n 682/PR; ADI n 2990/DF; ADI $n^{\circ} 1278 / \mathrm{SC}$; ADI $n^{\circ}$ 3756/DF; ADI-MC no 2238/DF; ADI no 3668/DF; ADI no 3458/GO; ADI nº 2999/RJ; ADI no 2649/DF; ADI $n^{\circ}$ 124/SC; AR-ED n 1373/DF; HC n 90900/SP; ADI n 3773/SP; ADI n 1980/PR; AI-QO n 132755/SP; ADI n

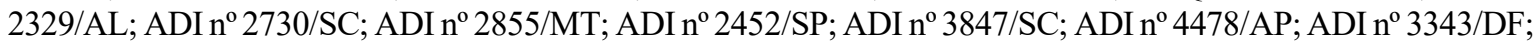
$\mathrm{ADI}^{\circ}$ 3041/RS; ADI-MC-Ref n ${ }^{\circ}$ 4638/DF; ADI n 2937/DF; MS nº 25125/DF; ADI n 1842/RJ; ADI n ${ }^{\circ} 2198 / \mathrm{PB}$; $\mathrm{ADI}^{\circ}$ 2818/RJ; ADI no 903/MG; RE-AgR no 775353/AC; ADI n 2922/RJ; ADI no 2886/RJ; RE no 336739/SC; ADI-AgR no 3074/DF; ADI no 4954/AC; ADI no 429/CE; ADI no 4423/DF; ADI no 4955/CE; ADI n 4093/SP; ADI-AgR no 4952/PB; ADI n 3813/RS; ADI no 4060/SC; ADI n ${ }^{\circ}$ 2615/SC; ADI n ${ }^{\circ}$ 5163/GO; RE n ${ }^{\circ}$ 422349/RS; $\mathrm{ADI}^{\circ}$ 5081/DF; ADI $n^{\circ}$ 3402/SP; ADI $n^{\circ}$ 3852/SC; RE ${ }^{\circ}$ 607940/DF; ADI ${ }^{\circ}$ 4912/MG; ADI $n^{\circ}$ 5286/AP; ADI $n^{\circ}$ 3835/MS; ADI n ${ }^{\circ}$ 5356/MS; ADI no 4861/SC; ADI n 5253/BA; ADI n ${ }^{\circ} 3735 / \mathrm{MS}$; RE-AgR n ${ }^{\circ}$ 775252/AC; ADI $n^{\circ}$ 2905/MG; RE nº 587970/SP; RE no 597854/GO; ADI no 4764/AC; ADPF no 273/MT; RE no 194704/MG; ADI $n^{\circ}$ 750/RJ; ADI n 2030/SC; ADI n 4066/DF; ADI n 3937/SP; ADI n 3470/RJ; ADPF n ${ }^{\circ}$ 109/SP; ADI n ${ }^{\circ} 3357 / \mathrm{RS}$; $\mathrm{ADI}^{\circ}$ 3356/PE; ADI $n^{\circ}$ 4984/CE; ADI no 4988/TO; ADI n ${ }^{\circ}$ 5462/RJ; ADI n ${ }^{\circ}$ 5312/TO; ADI $n^{\circ}$ 5352/SP; ADI $n^{\circ}$ 5077/DF; RE-AgR n 977595/SP; ADI nº 4633/SP; ADI nº 5486/SE; e ADI nº 4606/BA.
} 
e 384/PR, o RE no 286789/RS, a ADI no 3035/PR, a ADI-MC no 3774/RR, a ADI no 3669/DF, a $A D I n^{\circ}$ 2832/PR, o RE no 586224/SP, a ADI n 3059/RS e o RE-RG nº 1188352/DF. De todo modo, considerando que muitos desses casos são citados no conteúdo de decisões que integram a amostra ou foram localizadas por palavras-chave relacionadas ao tema, essas foram analisadas na presente pesquisa. Ressalte-se que é preciso estabelecer um critério objetivo de seleção de uma amostra cuja análise seja factível em uma pesquisa dessa natureza. Toda seleção importa na inclusão de certos casos e na exclusão de outros, o importante é que o critério adotado não importe na seleção dos casos que confirmam a hipótese de que se cogita.

Poder-se-ia, ainda, objetar que o recorte da presente pesquisa (ou seja, a interpretação que o STF faz do disposto nos $\S \S 1^{\circ}$ e $2^{\circ}$ do art. 24 da Constituição vigente) e a amostra levantada (ou seja, os casos julgados pelo STF em que tais dispositivos foram utilizados como parâmetro para o juízo de constitucionalidade orgânica vertical), por representaram apenas uma parte de todo o sistema constitucional de repartição de competências, não seriam suficientes para se traçar um diagnóstico completo do efeito das decisões da Corte sobre o processo de centralização do Estado federal brasileiro. Pelo que se depreende dos registros da ANC, os Constituintes pareciam estar conscientes da centralização que decorreria da previsão de dois extensos e detalhados catálogos de competências exclusivas e privativas da União (arts. 21 e 22, CR), combinados com uma cláusula de poderes reservados em favor dos Estados (art. $25, \S 1^{\circ}, \mathrm{CR}$ ), e procuraram contrabalançá-los com a previsão de dois outros importantes catálogos de competências compartilhadas com os entes subnacionais (arts. 23 e 24, CR), na expectativa de que esses últimos propiciassem uma "descentralização federativa gradual". Ocorre que a centralização de que se ressentem tantos observadores abarca não só as áreas e matérias de competência exclusiva e privativa da União, como as de competência comum e concorrente entre os entes federativos. Assim, embora as causas da centralização decorrente dos dois primeiros catálogos sejam conhecidas, as da que foi observada especialmente nas matérias do último catálogo, em relação às quais entende-se que os Constituintes procuraram delimitar o papel da União, ainda não foram suficientemente exploradas. É precisamente esse resultado que o recorte proposto pretende explicar. A hipótese de que se cogita, na presente pesquisa, é a de que isso se deve a uma combinação de fatores: $i$ ) os Constituintes tomaram tanto decisões centralizadoras como descentralizadoras; ii) ao tomarem decisões descentralizadoras, cometerem algumas falhas; e iii) decisões descentralizadoras que esses haviam tomado foram posteriormente revertidas pelo STF pela via interpretativa. 
Uma terceira objeção que poderia ser aqui levantada ao método aqui proposto é como se pode saber se a declaração da constitucionalidade ou inconstitucionalidade de uma lei ou ato normativo decorre do próprio texto constitucional ou de uma interpretação que foi a esse emprestada pela Corte. Em outras palavras, como saber se o resultado do julgamento é consequência de uma decisão da Corte e não de uma decisão do Constituinte. Essa é uma objeção importante, sobretudo levando em consideração que textos legislativos - tanto mais os constitucionais - dificilmente contêm um sentido unívoco, que não suscite mais de uma interpretação. É por isso que esse trabalho realizará, primeiramente, um esforço dogmático, no sentido de tentar identificar o que foi que os Constituintes pretendiam e o que esses de fato decidiram no que se refere às cláusulas de repartição de competências. Longe de ter uma preocupação com o "textualismo" ou com o "originalismo", tão presente no debate sobre a interpretação da Constituição nos EUA, o propósito dessa parte da pesquisa é aferir quanto a Corte se aproximou ou se distanciou do que pretendiam os Constituintes e do que, de fato, dispõe a Constituição. Isso porque, como se verá ao longo desse trabalho, alguns Ministros da Corte têm reconhecido abertamente que essa emprestou a determinadas cláusulas constitucionais de repartição de competências uma interpretação favorável à União e desfavorável aos entes subnacionais que remonta ao texto constitucional anterior. Mas, sem fazer a leitura das decisões, todas essas questões relevantes ficariam obscurecidas nos binômios procedência/improcedência da ação e lei nacional/subnacional. Sendo assim, longe de ser uma objeção, essa passa a ser um motivo para se embrenhar no complexo terreno da hermenêutica constitucional.

Ressalte-se, por fim, que William H. RIKER, um dos mais influentes autores da literatura internacional sobre federalismo no século XX, questiona estudos conduzidos por juristas que procuram extrair justamente esse tipo de conclusões a partir de decisões judiciais, alegando que essas não dimensionam áreas de competência dos diferentes entes federativos, quando muito demarcam seus limites diante de casos concretos:

"O defeito desse método é que decisões judiciais dizem respeito às
fronteiras das áreas de ação e de nenhuma maneira indicam seu tamanho
absoluto e importância. Apesar disso, a maior parte da história e análise
do federalismo foi escrita por constitucionalistas usando decisões judiciais
como matéria-prima. Como consequência, a tradição nos proporciona
uma imagem altamente distorcida da relação entre a nação e os Estados."

26 Tradução livre para: "The fault in this method is that judicial decisions concern the boundaries of areas of action and do not in any way indicate their absolute size and importance. Yet most of the history and analysis of federalism has been written by constitutional lawyers using judicial decisions as their raw material. As a 
Embora assista razão a RIKER ao dizer que o máximo que decisões judiciais podem fazer em matéria de federalismo é definir, casuisticamente, os limites que separam as áreas de competência dos diferentes entes federativos, ao que se sabe, a única maneira de se calcular uma área é conhecendo seus limites. Mas talvez RIKER não ficasse impressionado com um argumento, por assim dizer, de tipo geométrico. Em todo caso, se a esfera de competência de cada ente federativo encontra-se definida em disposições constitucionais e pode vir a ser redefinida, interpretativamente, por juízes e Tribunais, então justifica-se o estudo não só da repartição de competências, como de decisões judiciais - em especial da Suprema Corte, que é a suprema intérprete da Constituição. É claro que uma decisão judicial isoladamente jamais dará conta de indicar todo o volume de uma esfera de competência, mas o estudo sistemático de decisões judiciais pode oferecer uma ideia aproximada. De todo modo, é preciso ressaltar que não se está aqui propondo calcular, para fins de comparação, o volume das respectivas esferas de competência da União e dos Estados no Estado federal brasileiro; basta, para o propósito da presente pesquisa, observar se o STF, ao interpretar o texto constitucional, as fez expandir ou contrair, partindo de como essas haviam sido definidas pelos Constituintes. Isto é, não se pretende avaliar se o Estado federal brasileiro é centralizado ou descentralizado à luz da Constituição vigente, mas se esse se centralizou ou descentralizou a partir da promulgação dessa e se o STF teve uma participação nisso.

Embora essa não seja uma pesquisa propriamente de Direito comparado, alguma comparação com outros sistemas, especialmente o estadunidense, é inevitável, não só pelo fato de os EUA serem o berço tanto do Estado federal como da Jurisdição Constitucional, como pelo fato de que grande parte do debate a respeito de qual deve ser o papel a ser desempenhado pela Suprema Corte na resolução de conflitos federativos e sobre sua (ir)relevância para definir os rumos do federalismo ter sido travado naquele país. Dada a insistência de que os Constituintes, especialmente no que se refere às competências comuns e concorrentes e ao chamado federalismo cooperativo, teriam se inspirado no modelo alemão, alguma análise de disposições da Lei Fundamental de Bonn também foi necessária. O tema da centralização é multifacetado, pode ser encarado sob diferentes perspectivas, porque vários são os fatores que explicam esse processo. Assim, embora algumas leis envolvendo a questão do federalismo fiscal tenham sido abordadas, não se espere encontrar aqui uma discussão mais aprofundada sobre esse importante tema. Como se viu, o objeto

consequence the tradition provides us with a highly distorted picture of the relationship between the nation and the states." RIKER. William H. Federalism: origin, operation, significance. Boston: Little, Brown and company, 1964, p. 51. 
deste trabalho é apenas e tão-somente a centralização legislativa com foco nas competências concorrentes e serão analisadas aqui decisões do STF que, interpretando as cláusulas de repartição de competências, possam repercutir sobre esse processo.

Além dessa introdução e das conclusões finais, o presente trabalho compõe-se de quatro capítulos:

(i) o primeiro procura enfrentar a questão da ausência de consenso na literatura quanto ao conceito de federalismo e da (ir)relevância da distinção binária entre Estados federais e unitários e esclarecer que instituições federativas interferem no processo de (des)centralização e, por fim, aborda as origens comuns do federalismo e do judicial review nos EUA e procura extrair lições do debate estadunidense sobre o papel e a relevância da Suprema Corte na definição dos rumos do federalismo;

(ii) o segundo procura compreender que modelo de Estado federal e que sistema de repartição de competências que os Constituintes efetivamente adotaram, na medida em que as disposições constitucionais podem não revelar aquilo que esses rechaçaram, bem como fazer uma defesa de um conceito positivo de normas gerais, diverso da ideia de "lacunas preenchíveis", e que ofereça um teste rigoroso com o qual o STF possa efetivamente controlar a extrapolação da competência da União;

(iii) o terceiro aborda a questão do vício de inconstitucionalidade orgânica, foco do presente trabalho, que é aquele que se dá quando uma norma é editada por sujeito diverso daquele a quem a Constituição atribui a competência, bem como analisa como o STF vem decidindo casos que envolvem as chamadas competências concorrentes e como esse vem interpretando o disposto nos $\S \S 1^{\circ}$ e $2^{\circ}$ do art. 24 da Constituição vigente;

(iv) o quarto e último capítulo analisa a anunciada nova jurisprudência do STF em matéria de federalismo, procurando avaliar em que medida essa é realmente nova e atende aos anseios dos Constituintes, também se fará um exame das propostas feitas por Ministros para que a Corte revise seu entendimento. 


\section{CONCLUSÕES}

Procurou-se demonstrar no presente trabalho que, embora muitos autores estejam corretos ao apontar que a Constituição brasileira vigente é, de modo geral, centralizadora, parte significativa da centralização observada após a sua promulgação deve-se, na realidade, a uma atuação expansiva do Congresso Nacional combinada com a adoção de uma postura de autocontenção por parte do STF. A rigor, dada a característica da sua inércia, a Corte não promove ela própria centralização ou descentralização; porém, ao possuir a última palavra em matéria constitucional, o que inclui as cláusulas de repartição de competências, possui a capacidade de conter ou de chancelar esses processos, o que a torna, sem dúvida alguma, um ator relevante. Pois bem, como se viu, o sistema de repartição de competências adotado na Constituição é bastante complexo: combina técnicas de inspiração diversa e contém múltiplas listas que apontam em diferentes direções, sem mencionar as competências que se encontram dispersas ao longo do texto constitucional. Assim, ao mesmo tempo em que essa prevê, nos arts. 21 e 22, dois extensos e detalhados catálogos de competências exclusivas e privativas da União, contém nos arts. 23 e 24 dois outros importantes catálogos de competências comuns e concorrentes com os entes subnacionais. Ao que se depreende dos relatórios da $\mathrm{ANC}$, os Constituintes supunham que, ainda que os dois primeiros ensejassem centralização, os dois últimos propiciariam um processo de "descentralização federativa gradual", ao menos quanto às matérias neles relacionadas, o que, como se sabe, acabou não se confirmando. Mas, afinal, com quem está a razão na controvérsia a respeito de a quem deve ser atribuída a centralização do federalismo brasileiro: com os que a atribuem a escolhas dos Constituintes ou com aqueles que a associam a outros atores? Além disso, o que explica a frustração das expectativas dos Constituintes, supondo que essas fossem mesmo genuínas, em relação à trajetória do federalismo brasileiro?

Entende-se aqui que, no que se refere à definição do modelo de Estado federal e ao sistema de repartição de competências entre os entes federativos, os Constituintes tomaram, na realidade, tanto decisões centralizadoras como descentralizadoras, porém essas últimas costumam ser completamente negligenciadas nos estudos dedicados ao tema. Assim, se é certo que a centralização decorrente da extensão e do detalhamento dos catálogos de competências exclusivas e privativas da União deve-se a escolhas dos Constituintes, não é tão certo que a (somente) esses deva ser atribuída a centralização observada nas matérias de competência concorrente, em relação às quais outro resultado era não só possível, como até mais coerente com o disposto na Constituição. Afinal, como se viu, ao inserirem o comando 
"limitar-se-á" e ao substituírem o termo "supletivamente" por "suplementar" nos $\S \S 1^{\circ}-2^{\circ}$ do art. 24, respectivamente, esses introduziram modificações importantes à sistemática das competências concorrentes prevista no texto constitucional anterior. Todavia, ao contrastar as limitações impostas pelos Constituintes ao exercício da competência da União nessas matérias com a edição de chamadas "normas gerais exaurientes" pelo Congresso Nacional e a deferência que o STF por muito tempo adotou em relação a essa prática, fica difícil escapar à conclusão de que, ao menos em relação a essas matérias, as regras constitucionais não explicam o resultado. Mas, se não a Constituição, então o que explica a centralização observada nas matérias de competência concorrente?

Os achados da presente pesquisa demonstram que, ao interpretar a Constituição, o STF não só deixou de explorar o potencial descentralizador das diretrizes restritivas ao exercício da competência da União que foram insculpidas pelos Constituintes nos $\S \S 1^{\circ}-2^{\circ}$ do art. 24, como na realidade parece ter "repristinado" o conceito de normas gerais que havia sido formulado à luz do texto constitucional anterior, que é de todo incompatível com a ordem constitucional vigente, aplicando um teste pouco rigoroso para controlar a atividade legislativa da União nessas matérias. Mais do que isso: além de relaxar as restrições que os Constituintes haviam imposto ao exercício da competência da União nas matérias de competências concorrentes, a Corte chegou inclusive a desdobrar a partir do trecho "para atender a suas peculiaridades" previsto no $\S 3^{\circ}$ do mesmo artigo restrições que, a princípio, não haviam sido por aqueles impostas ao exercício da competência dos Estados nessas matérias. Não se pretende com isso eximir os Constituintes de qualquer participação no processo de centralização do federalismo brasileiro observado após a promulgação da Constituição, porém não se pode deixar de registrar que importantes decisões descentralizadoras que foram por esses tomadas, em pontos em que pretendiam romper com o passado, foram posteriormente revertidas pela Corte pela via hermenêutica. Por outro lado, hoje se sabe, com o benefício da perspectiva, que os Constituintes falharam ao terem deixado de estabelecer, no próprio texto constitucional, parâmetros mais claros daquilo que a União poderia ou não fazer a título de editar normas gerais. Sendo assim, pode-se dizer que os Constituintes, tanto quanto o Congresso Nacional e o STF, são cada qual em certa medida corresponsáveis pelo processo de centralização observado nas matérias de competência concorrente no período pós-1988.

Não se está aqui evidentemente a defender a prevalência do elemento histórico de interpretação constitucional sobre os demais. O objetivo de se examinar (Ante)projetos de Constituição, emendas, destaques e relatórios apresentados, bem como discursos proferidos 
no decorrer dos trabalhos da ANC não era propriamente o de identificar qual era a intenção dos Constituintes, ainda que se considere isso sim relevante. Como se explicou na introdução desse trabalho, pretendeu-se com isso distinguir as escolhas que foram feitas pelos Constituintes das escolhas que foram feitas posteriormente pelo STF - algo bastante difícil de se realizar na prática considerando que Constituições se consubstanciam em textos que demandam interpretação, mas indispensável se o que se pretende é isolar as decisões da Corte das decisões da ANC, a fim de se poder avaliar qual foi o seu efeito. De todo modo, entendese aqui que a conclusão a que se chegou, no sentido de que os $\S \S 1^{\circ}-2^{\circ}$ do art. 24 encerram diretrizes restritivas do exercício da competência da União nessas matérias, é compatível não só com o elemento histórico como com os elementos sistemático e teleológico de interpretação constitucional. Afinal, as modificações que foram ali introduzidas pelos Constituintes são coerentes com modificações que esses fizeram em outras disposições constitucionais, como a previsão contida no caput do art. 18 de que União seria somente mais um ente federativo dotado de autonomia. Além disso, a inserção do comando "limitar-se-á" no $\S 1^{\circ}$ e a substituição do termo "supletivamente" por "suplementar" no $\S 2^{\circ}$ do art. 24 não parecem deixar margem para dúvidas de que seu propósito era o de conter o alcance da competência da União nessas matérias.

Outro aspecto que parece explicar a frustração das expectativas dos Constituintes com relação ao processo de descentralização gradual do federalismo brasileiro é o efeito esperado da adoção da técnica do compartilhamento de competências. Viu-se que esses teriam considerado que, naquele momento, o país ainda não estaria preparado para uma descentralização abrupta, obtida por meio da transferência pura e simples de competências exclusivas e privativas da União para os entes subnacionais. Por essa razão, teriam optado por um processo de descentralização a ser alcançado mediante a ampliação das áreas e matérias de competência compartilhadas com os entes subnacionais. Ocorre que o mero compartilhamento de competências entre os entes federativos não produz necessariamente descentralização - isso, na realidade, depende das disposições que definem o papel que cada qual deve desempenhar em relação às áreas e matérias por esses compartilhadas. Afinal, como se viu, é possível combinar descentralização executória com centralização decisória. Assim, ao deixarem de definir parâmetros mais claros sobre aquilo que a União poderia ou não fazer a título de editar normas gerais, os Constituintes acabaram abrindo caminho para que essa pudesse avançar sobre o campo destinado à suplementação por parte dos entes subnacionais. Como consequência, a diversificação cedeu espaço à uniformização. 
Como se viu, a Corte por muito tempo trabalhou com um conceito de normas gerais que havia sido desenvolvido à luz do texto constitucional anterior, segundo o qual bastava que essa, ao editá-las, deixasse lacunas a serem supridas (as chamadas “lacunas preenchiveis") pelos entes subnacionais, o que permitia, na prática, que a União definisse ela própria até onde poderia ir ao regular as matérias de competência concorrente. É preciso reconhecer, no entanto, que esse conceito não cria verdadeiramente limites ao exercício da competência legislativa da União nessas matérias, ou melhor, faz com que essa limitação, no fundo, dependa da adoção de uma postura de autocontenção por parte do Congresso Nacional, o que não se deve esperar que ocorra. Embora Madison estivesse de fato mais preocupado com o descumprimento dos limites impostos pela Constituição aos Estados, o que é perfeitamente compreensível dado o desenho dos artigos da Confederação e o contexto do pós-guerra de independência, ele partia do pressuposto de que, ao se desenhar instituições, seria preciso atentar para que essas não criassem incentivos para desvios. Surpreende que a Corte pareça não ter percebido que, na realidade, tal conceito não estabelece qualquer parâmetro para controle da atividade da União nas matérias de competência concorrente, haja vista que é praticamente impossível que o legislador ordinário esgote toda a regulação de uma matéria, afinal ele não consegue antecipar todas as suas possíveis aplicações. Portanto, dificilmente uma lei editada pela União seria, com base nesse conceito, declarada inconstitucional por extrapolar do âmbito das normas gerais, o que foi confirmado pelos achados desse trabalho. Assim, não surpreende que os raríssimos casos identificados nessa pesquisa de leis editadas pela União que foram declaradas inconstitucionais pelo STF ou que foram por esse preservadas somente por meio da adoção da técnica da interpretação conforme à Constituição refiram-se, na realidade, a leis que interferem diretamente na Administração dos Estados, ou seja, o foram mais por interferir na autonomia dos entes federativos (art. 18, caput, CR) do que por extrapolar do conteúdo de normas gerais (art. 24, §1 $\left.{ }^{\circ}, \mathrm{CR}\right)$.

Embora o art. 24 da Constituição vigente, a princípio, não contenha restrições ao exercício da competência suplementar dos entes subnacionais, viu-se que a prática parece ter originado, por meio de uma interpretação a contrario sensu do disposto em seu $\S 3^{\circ}$, uma espécie de restrição ao exercício da competência dos Estados nessas matérias. Parte-se do seguinte raciocínio: se os Estados só podem legislar sobre normas gerais em caso de omissão da União em editá-las, então, em havendo essas, aqueles estariam obrigados a observá-las. Defendeu-se aqui que essa interpretação é compatível com a Constituição, na medida em que, embora não haja hierarquia entre a lei editada pela União e a lei editada 
pelos entes subnacionais, cada ente deve observar seu campo próprio (a União com as suas normas gerais e os Estados com a sua suplementação), sob pena de inconstitucionalidade por usurpação de competência. Até porque, ainda que se ressalte aqui a intenção dos Constituintes em restringir o exercício da competência da União nessas matérias, isso não significa que os entes subnacionais estariam livres para desrespeitá-las, simplesmente porque esses não o disseram expressamente. Afinal, todo ente ou Poder do Estado deve agir dentro do campo que lhe foi designado, do contrário não se teria uma Constituição limitada, como defendeu Hamilton.

Mas, se não as disposições constitucionais, então o que explica o comportamento da Corte e sua variação ao longo do tempo? Não se observou, nos achados dessa pesquisa, maiores divergências entre os Ministros do STF no que se refere ao conceito de federalismo, seu significado histórico, suas implicações para as relações intergovernamentais ou, mesmo, do papel a ser desempenhado pela Corte ao arbitrar disputas entre os entes federativos. Com relação a esse aspecto, o "debate" entre eles foi até bastante monótono. Assim como os Constituintes, os Ministros da Corte parecem, de modo geral, associar federalismo com democracia e entender que o Estado federal significa descentralização. Claro que o fato de, aparentemente, não haver divergência entre eles não significa necessariamente que essa de fato não exista, é possível que os Ministros estejam de acordo em termos conceituais, porém divirjam profundamente quanto à importância relativa de seus elementos. Supõe-se aqui que um fator relevante para explicar algumas decisões da Corte seja a diferença no peso que os diferentes Ministros atribuem aos imperativos da uniformidade e da diversidade, o que, no fundo, não deixa de ser uma divergência sobre federalismo. Pode-se citar, por exemplo, o julgamento da $\mathrm{ADI} \mathrm{n}^{\mathrm{o}}$ 2.905/MG, em que a existência, no território nacional, de diferentes regimes de direito do consumidor (o que configura "venda casada" em um Estado pode ser diferente em outro?), foi encarada como um inconveniente por parte de alguns Ministros, ainda que essa matéria seja de competência concorrente. Juridicamente isso se traduziu na controvérsia sobre se a existência de peculiaridade regionais/locais seria um requisito apenas para o exercício da competência supletiva ou também para a suplementar dos Estados.

Ademais, como demonstra a análise das ADIs n ${ }^{\circ} 3.367 / \mathrm{DF}$ e 4.638/DF, relativas à criação do $\mathrm{CNJ}$ pela EC no 45/2004 e às competências que se lhe foram cometidas, a maioria dos Ministros da Corte esposa o entendimento de que o Poder Judiciário teria caráter nacional, ainda que estruturado nos âmbitos federal e estaduais. Por isso, os atos do CNJ, órgão que compõe a estrutura do Poder Judiciário, mas que não exerce competência jurisdicional e sim 
meramente administrativo-fiscalizatória, poderiam interferir nos TJs estaduais. Sendo assim, o STF, que é o órgão de cúpula de um Poder nacional e não meramente federal, não só não estaria vinculado aos Estados, DF e Municípios, como tampouco à União, o que lhe permitiria desenvolver seu papel arbitral, no que diz respeito a questões federativas, com maior independência.

Os Ministros também parecem ter sido cautelosos ao controlar a constitucionalidade de algumas leis editadas pela União que contêm disposições que aparentemente desbordam do conteúdo de normas gerais, mas que representaram, à época de sua edição, avanços em matéria de gestão pública. Afinal, o reconhecimento da extrapolação da competência da União nessas matérias e, portanto, da inconstitucionalidade da lei, com seus consectários como a sanção da nulidade, poderia significar, nesses casos, um retrocesso. A exemplo do que sucedeu no julgamento da ADI n ${ }^{0}$ 927/RS, em que se questionou a constitucionalidade de disposições da Lei no 8.666/1993 (Lei Geral de Licitações e Contratos Administrativos), a solução encontrada para a preservação das disposições da lei foi a adoção da técnica da interpretação conforme à Constituição ou da declaração de nulidade parcial sem redução de texto, de modo a restringir a aplicação de tais disposições à União ou vedá-la em relação aos entes subnacionais, respectivamente. Defendeu-se aqui ser preferível, nesses casos, a adoção da segunda técnica pelo efeito pedagógico que a pronúncia da inconstitucionalidade de uma lei editada pela União que extrapola o conteúdo de normas gerais pode exercer sobre as relações federativas.

Aliás, se o que levou a Corte a "repristinar", em um primeiro momento, o conceito de normas gerais formulado à luz da $\mathrm{EC} \mathrm{n}^{\circ}$ 01/1969 - que, como se disse, é de todo incompatível com o da Constituição de 1988 - foi a antecipação das consequências que o reconhecimento da não-recepção da legislação que havia sido editada pela União nessas matérias antes do advento da nova ordem constitucional poderia ocasionar, o "apelo ao legislador" pode ser um meio de exortar o Congresso Nacional a revisar o "entulho centralizador" herdado do regime anterior. Do mesmo modo, se o STF de fato pretende rever a tendência centralizadora de sua jurisprudência sobre federalismo e adotar uma interpretação dos $\S \S 1^{\circ}-2^{\circ}$ do art. 24 mais consentânea com os anseios dos Constituintes, mas ao mesmo tempo receia as consequências que a declaração de inconstitucionalidade de uma lei editada pela União nessas matérias pode ter, uma solução é lançar mão de outras técnicas de decisão, como a do processo de inconstitucionalização (ou da lei ainda constitucional), sinalizando claramente 
ao Congresso Nacional que passou a adotar um conceito mais restritivo de normas gerais e que, a partir de então, aplicará um teste mais rigoroso a respeito do que essas vêm a ser.

Supondo-se que o overruling anunciado, à unanimidade, pela Corte em 2015 tenha de fato ocorrido (algo que não pode ser tomado como um dado, é preciso ser confirmado) e considerando que não houve reforma dos parágrafos do art. 24 da Constituição, o que explicaria esse movimento? Em um artigo publicado em 2013, o Min. Ricardo Lewandowski observou que: "No Supremo Tribunal Federal, considerada a sua atual composição, já há uma visível tendência no sentido do fortalecimento do federalismo, prestigiando-se a autonomia dos estados e municípios, a partir de inúmeras decisões, especialmente nas áreas da saúde, meio ambiente e do consumidor. ${ }^{\circ 28}$ Esse argumento parece partir de uma premissa bastante difundida na literatura no sentido de que, sendo a Corte um órgão colegiado, suas decisões podem ser explicadas pela preferência da maioria dos membros que participam do julgamento e a variação de seu entendimento pelas maiorias que foram se formando ao longo do tempo. Duas hipóteses que já foram cogitadas na literatura e que podem ser aqui testadas são as de que as preferências dos Ministros refletiriam as suas origens territoriais ou, ainda, a orientação do partido político a que está afiliado o Presidente que os indicou. Nenhuma dessas variáveis, no entanto, parece explicar que a suposta mudança de orientação da Corte tenha ocorrido em 2015: juntas as regiões Sudeste e Sul nunca tiveram menos de 6 Ministros (1989), ou seja, sempre foram maioria no Pleno da Corte desde a promulgação da Constituição vigente. O sudeste sozinho nunca teve menos de 5 (1989) e já chegou a ter 9 (1995 e 2011) nesse período. Curiosamente, o período em que a Corte teve o maior número de Ministros de outras regiões (4 Ministros do Nordeste) foi logo no início da vigência da atual Constituição (1988-1989), ou seja, a composição da Corte herdada do regime anterior. Apenas a título de curiosidade, os Estados que mais tiveram Ministros, em um dado momento, na Corte foram: Rio de Janeiro (4 em 2011; 2014-2018); Minas Gerias (4 em 1997 e 2004) e São Paulo (3 de 1990-2003; 2011-2012 e 2018). Outro dado curioso é que, supondo-se que o Sudeste e o Sul, por serem as regiões mais ricas e desenvolvidas do país, teriam maior interesse pela descentralização, o domínio dessas regiões ao longo de todo o período pós-1988 não explica a tendência centralizadora da Corte. Assim, ao que tudo indica, os Ministros do STF não se comportam como se fossem representantes de suas respectivas regiões.

${ }^{628}$ LEWANDOWSKI, Enrique Ricardo. Considerações sobre o federalismo brasileiro. Justiça \& Cidadania, n. 157 , set. 2013, p. 17. 
Tampouco a variável partido político do Presidente que os indicou parece explicar a mudança na orientação da Corte: afinal, os Ministros que foram indicados por Presidentes afiliados ao PT são maioria (pelo menos 6) no Pleno da Corte desde 2007, tendo chegado ao número de 8 em 2012, 2014 e 2016-2017. Considerando que o ex-Presidente Fernando Henrique Cardoso, embora tenha sido reeleito e governado o país por 8 anos, indicou somente 3 Ministros ao STF (menos que o ex-Presidente Fernando Collor de Mello, que em menos de um mandato, indicou 4), os Ministros que foram por esse indicados nunca chegaram a formar maioria no Pleno da Corte. Assim, como se vê, dos dois partidos que, por mais tempo, elegeram Presidentes da República desde 1988, somente os Ministros indicados por Presidente afiliados ao PT formaram maioria no Pleno da Corte. Considerando que, pelo critério temporal, essa variável pode ser descartada para explicar a mudança da orientação na Corte com relação ao tema, não há aqui necessidade de testar a coesão desse conjunto de Ministros (para determinar se esses funcionam como um bloco). Ademais, diferentemente dos EUA, onde diversos Presidentes afiliados ao Partido Republicano se posicionaram pela reversão do processo de centralização e se comprometeram a indicar para a Suprema Corte somente Justices com essa mesma posição, no Brasil dificilmente a questão federativa ganha contornos ideológicos, a ponto de se poder distinguir os partidos com base em critérios relacionados a federalismo. Ao que tudo indica, aquelas decisões tomadas por maiorias apertadas (de 5x4) em matéria federativa, refletindo as divisões partidárias dentro da composição da Corte, é realmente algo característico dos EUA. Assim, essas teorias que parecem, em alguma medida, explicar o comportamento dos Justices da Suprema Corte dos EUA parecem não ser muito explicativas do caso brasileiro.

Procurou-se demonstrar aqui ainda que, a despeito da sinalização expressa de um prospective overruling quando do julgamento da ADI no 4.060/SC em 2015, não houve de fato, até o presente momento, uma mudança radical na jurisprudência do STF concernente ao federalismo. O que se vê claramente é que os Ministros têm se mostrado, cada vez mais, conscientes da necessidade de rever a orientação centralizadora que a Corte vinha mantendo em relação ao tema e dispostos a desenvolver novas abordagens para enfrentar essa questão. Com efeito, três abordagens puderam ser identificadas nesse movimento recente da Corte: a primeira foi defendida pela Minª Cármen Lúcia, na linha do Min. Ayres Britto, em seu voto proferido na ADI n ${ }^{\text {o }}$ 2.905/MG, no sentido de extrair, das cláusulas constitucionais de repartição de competências, uma interpretação mais consentânea com a descentralização com a qual os Constituintes tanto ansiavam; a segunda e provavelmente a mais conhecida 
seja aquela que foi capitaneada pelo Min. Luiz Fux, com o apoio de seus pares na Corte, no julgamento da referida $\mathrm{ADI} \mathrm{n}^{\mathrm{o}}$ 4.060/SC, propondo o reconhecimento de uma presunção de constitucionalidade em favor das leis editadas pelos entes subnacionais ("in dubio pro autonomia" dos entes subnacionais); e a última foi aquela proposta pelo Min. Edson Fachin, em seu voto proferido no RE n ${ }^{\circ}$ 194.704/MG, que também propõe a adoção de uma presunção em favor dos entes subnacionais (a chamada "presumption against pre-emption"), mas desloca a esfera de decisão do STF para o Congresso Nacional, na medida em que admite que essa presunção possa ser afastada por indicação expressa na lei (a chamada "clear statement rule", ambas do Direito estadunidense). É preciso reconhecer que todas essas abordagens possuem virtudes inegáveis: a primeira por trabalhar o próprio parâmetro de controle, ou seja, a própria Constituição, com vistas a desdobrar, interpretativamente, parâmetros mais claros e consentâneos com os anseios dos Constituintes para aferir a constitucionalidade das leis; a segunda por identificar a própria jurisprudência da Corte como uma das causas da centralização do federalismo brasileiro, conclamando-a a rever sua orientação e passar a contemplar, em nome do pluralismo, as iniciativas dos entes subnacionais; e a terceira por questionar se os critérios previstos na Constituição não acabam fazendo prevalecer sempre, em caso de conflito, a lei editada pela União e procurar identificar, na experiência comparada, princípios para reinterpretá-la de modo a extrair outros critérios que permitam chegar a um resultado diferente.

Examinando a questão da perspectiva dos entes subnacionais, a Min ${ }^{a}$ Cármen Lúcia, em sua abordagem hermenêutica, levantou alguns pontos importantes: primeiro, o conceito de normas gerais visa a restringir somente o exercício da competência da União, não a dos entes subnacionais, nessas matérias; segundo, a existência de peculiaridades regionais/locais não pode ser considerada requisito para o exercício da competência suplementar, mas somente a supletiva, pelos entes subnacionais, sob pena de esvaziamento de sua participação nas competências concorrentes. Embora a Ministra tenha razão ao sustentar que o conceito de normas gerais está voltado a limitar a competência da União e não a dos entes subnacionais, não se pode perder de vista que, na prática, as noções de normas gerais e de suplementação são vaso comunicantes: a expansão de um leva necessariamente à contração do outro. Quanto ao segundo ponto, defendeu-se aqui que a existência de peculiaridades regionais/ locais não é requisito para o exercício nem da competência suplementar, nem da supletiva. Afinal, não se pode admitir que, à falta de normas gerais sobre uma determinada matéria, os entes subnacionais, para que possam supri-las, estejam condicionados à existência de 
peculiaridades regionais/locais. Tal visão parece já partir do pressuposto de que a União não respeita os limites de sua competência para editar apenas normas gerais; do contrário, caso a União seja omissa ao editar normas gerais e não haja, naquele caso, peculiaridades regionais/locais, ter-se-ia simplesmente uma situação de anomia, ou seja, de ausência total de normas, tanto gerais como específicas, sobre uma determinada matéria. Defendeu-se aqui que a interpretação mais adequada desse dispositivo é que a ausência de normas gerais não pode obstar os entes subnacionais de regularem a matéria, estando ou não presentes peculiaridades locais.

Assim, como se pode ver, nas matérias de competência concorrente, dois fatores relacionados à interpretação das cláusulas constitucionais de repartição de competências parecem explicar a centralização legislativa que foi observada pelos Ministros: de um lado, a adoção de um conceito de normas gerais tão amplo que praticamente não oferece qualquer teste para o controle das leis que são editadas pela União nessas matérias; e, de outro, a exigência da existência de peculiaridades regionais/locais que justifiquem o exercício pelos entes subnacionais de sua competência tanto suplementar como supletiva nas matérias de competência concorrente. Com isso, tem-se a reversão das diretrizes fixadas pelo próprio Constituinte, que restringiu ("limitar-se-á" e "não exclui") o exercício da competência da União nas matérias de competência concorrente, mas não o fez em relação aos Estados. Assim, a interpretação feita pela Min $^{a}$ Cármen Lúcia parece ser mais consentânea com a intenção dos Constituintes que, se acertaram ao limitar o exercício da competência da União nas matérias de competência concorrente, falharam ao deixar de definir parâmetros mais claros sobre o que esse pode ou não fazer a título de editar normas gerais.

Já a saída encontrada pelo Min. Luiz Fux, no sentido de se reconhecer, em nome do pluralismo, uma presunção de constitucionalidade das leis editadas pelos entes subnacionais (“in dubio pro autonomia" dos entes subnacionais), que só se afastaria em caso de ofensa a norma constitucional "expressa e inequívoca", parece oferecer mais dificuldades do que soluções. Afinal, todas as leis, inclusive as que foram editadas pela União, presumem-se constitucionais, até que se constate a ocorrência de ofensa clara a uma norma constitucional, tanto expressa como implícita (não por outra razão que se exige maioria qualificada para que se possa pronunciar a inconstitucionalidade de uma norma). Se as leis editadas pela União, inclusive as normas gerais, também gozam de presunção de constitucionalidade, como se pode esperar que o reconhecimento de uma presunção de constitucionalidade em favor das leis dos entes subnacionais possa resolver o problema da contrariedade da lei estadual suplementar 
com a norma geral da União? A solução proposta pelo Min. Edson Fachin, com base no princípio da subsidiariedade, também envolve uma presunção em favor dos entes subnacionais (a "presumption against pre-emption"), que só se afastaria na hipótese de a União manifestar essa intenção expressamente na lei (a “clear statement rule”). Nos EUA, isso é possível porque a Constituição contém uma Supremacy Clause que faz com que a legislação federal goze de supremacia em relação à legislação estadual, o que - como se viu - não é o caso brasileiro. No Brasil, diferentemente, não só não consta uma cláusula de supremacia, como qualquer suposição de hierarquia entre a legislação federal e estadual parece ter sido rechaçada pelos Constituintes. Assim, essa solução que coloca a decisão, em última análise, nas mãos do Congresso Nacional tampouco parece compatível com as escolhas dos Constituintes.

De todo modo, não se deve carregar nas críticas dirigidas à jurisprudência da Corte em matéria federativa ${ }^{629}$, afinal os Ministros se veem constantemente na contingência de resolver questões que foram deixadas em aberto pelos Constituintes. Até porque, como se viu, o sistema de repartição de competências previsto na Constituição vigente, ou seja, o próprio parâmetro do controle de constitucionalidade, é complexo, às vezes assistemático e contém falhas. Mas, se o STF não pode ser responsabilizado pelas escolhas centralizadoras que foram feitas pelos Constituintes, nem pelos erros que foram por esses cometidos ao tomarem decisões descentralizadoras, aquele pode ser sim responsabilizado por ter revertido decisões descentralizadoras que haviam sido por esses tomadas. De todo modo, a Corte parece estar, de fato, cada vez mais consciente dos erros cometidos no passado e procurando corrigir essa tendência centralizadora na sua jurisprudência. É preciso observar, no entanto, que um passo importante foi dado nos últimos anos: passou-se da mera constatação de que a orientação da Corte é centralizadora para a busca de critérios para revertê-la. Com efeito, são os próprios Ministros que estão reconhecendo sua parcela de culpa pela centralização do federalismo brasileiro e são eles próprios que estão propondo rever sua orientação. Os Ministros estão fazendo as perguntas certas: é possível extrair da Constituição uma interpretação mais consentânea com a intenção dos Constituintes? É possível se chegar a um resultado diferente nos casos envolvendo conflito entre leis de diferentes entes federativos? É possível reverter a tendência manifestada pela Corte no passado em relação a questões federativas?

\footnotetext{
${ }^{629}$ Ressalte-se que, mesmo a jurisprudência da Suprema Corte dos EUA em matéria de federalismo, que é estudada no mundo todo é, às vezes, duramente criticada pela Academia.
} 
Poder-se-ia questionar onde fica o papel do Senado nisso tudo? Não caberia a esse, como Câmara de representação territorial, resguardar o interesse dos Estados? Ou caberia ao STF, na qualidade de guardião da Constituição, zelar para que a esfera de competências dos Estados fosse preservada? Aliás, o debate estadunidense é bastante rico a esse respeito: as chamadas "salvaguardas do federalismo" devem ser de tipo político ou jurisdicional? Isto é: a quem cabe proteger os Estados? De todo modo, é preciso observar que, nos EUA, o Senado possui uma larga tradição como Casa da Federação, sendo que, até o advento da Décima Sétima Emenda em 1913, os senadores eram indicados pelas suas respectivas Assembleias Legislativas. No Brasil, por outro lado, onde esses sempre foram escolhidos pelos eleitores de seus respectivos Estados (à exceção dos senadores biônicos durante o regime militar), essa discussão perde um tanto sentido. É que, como se viu, pesquisas empíricas recentes mostram que o padrão de comportamento dos senadores brasileiros não é explicado pela sua origem territorial, mas sim por sua filiação partidária. Sendo assim, como se espera que esses venham a proteger os Estados de eventuais intrusões da União em sua esfera de competências? Pode ser que, na prática, a única salvaguarda de que os Estados efetivamente dispõem no Brasil seja de tipo jurisdicional, o que ressalta a importância do STF.

Da amostra de 140 casos analisados na presente pesquisa, somente $19^{630}$ (20, em se computando o RE $\mathrm{n}^{\mathrm{o}} 128272 / \mathrm{DF}$ ) tiveram por objeto a constitucionalidade de leis ou atos normativos editados pela União, dos quais: 7 foram propostos por confederações sindicais ou entidades de classe de âmbito nacional (art. 103, IX, CR), 3 por partidos políticos com representação no Congresso Nacional (art. 103, VIII, CR), mesmo número dos propostos por Governadores de Estado ou do DF (art. 103, V, CR), 2 pelo PGR (art. 103, VI, CR) e 1 pela Mesa Diretora da Câmara Legislativa do DF (art. 103, IV, CR), sendo que os demais envolveram controle concreto de constitucionalidade. Como se vê, mesmo com o recorte dos $\S \S 1^{\mathrm{o}}$ e $2^{\mathrm{a}}$ do artigo 24 da Constituição vigente, poucos foram os casos da amostra em que se questionou a constitucionalidade de lei ou ato normativo editado pela União, pouquíssimos foram os que foram propostos por legitimados ligados aos Estados ou ao DF (por Governador e por Mesa Diretora do Poder Legislativo regional). Esse achado não deixa de ser surpreendente, considerando que se procurou selecionar os casos com base justamente nos

\footnotetext{
${ }^{630}$ São essas: ADI-MC n 1127/DF; ADI-QO nº 1885/DF; ADI-MC nº 2024/DF; ADI no 1600/UF; ADI-MC $n^{\circ}$ 1931/DF; ADI no 2591/DF; RE-QO nº 430105/RJ; ADI n 3756/DF; ADI-MC no 2238/DF; ADI n ${ }^{\circ} 2999 / \mathrm{RJ}$; ADI $n^{\circ}$ 2649/DF; ADI-MC-Ref no 4638/DF; ADI n 2937/DF; ADI no 2198/PB; ADI-AgR n 3074/DF; ADI $n^{\circ} 5081 / \mathrm{DF} ; \mathrm{RE} \mathrm{n}^{\circ} 587970 / \mathrm{SP} ; \mathrm{RE} \mathrm{n}^{\circ} 597854 / \mathrm{GO}$; ADI nº 4066/DF.
} 
dispositivos constitucionais que limitam a competência legislativa da União para editar normas gerais.

Desses 19 casos que têm por objeto leis ou atos normativos editados pela União, somente 2 foram julgados totalmente procedentes (a título definitivo ou precário), dos quais um foi proposto pelo PGR e o outro por uma entidade de classe, e 5 parcialmente procedentes (a título definitivo ou precário), sendo 3 propostos por confederações sindicais ou entidades de classe, 1 pelo PGR e 1 por partido político. Chama de fato atenção o número baixo de casos propostos por autoridades ligadas aos Estados ou ao DF e o fato de que nenhum desses tenha sido julgado procedente ou parcialmente procedente. De todo modo, se desprezados os 3 casos (4, se incluído o RE n $\left.{ }^{\circ} 128272 / \mathrm{DF}\right)$ de controle concreto de constitucionalidade, que parecem não envolver os $\S \S 1^{\circ}$ e $2^{\circ}$ do artigo 24 da Constituição vigente, verifica-se que o índice de sucesso das ADIs que têm por objeto leis e atos normativos editados pela União nessa amostra não foi tão baixo assim, aproximando-se da metade $(43,75 \%)$. A análise do conteúdo das decisões, porém, leva a uma conclusão muito diferente. Nenhuma das ADIs julgadas procedentes ou parcialmente procedentes o foi por vício de inconstitucionalidade orgânica (de que se cogita com base no art. $24, \S \S 1^{\circ}$ e $2^{\circ}, C R$ ): a que foi proposta pelo PGR foi julgada procedente por não se considerar extensível a hipótese de perda de cargo por infidelidade partidária prevista em Resolução do TSE aos cargos eletivos pelo sistema majoritário; já a que foi proposta pela entidade de classe de âmbito nacional foi julgada procedente por entender que a lei editada pela União que disciplina as atividades envolvendo amianto prevê uma proteção insuficiente aos direitos fundamentais à saúde e ao meio ambiente equilibrado.

Além disso, foi possível observar: em alguns casos, não só a AGU, a quem a Constituição confiou a missão de defender a lei ou ato normativo cuja constitucionalidade fora questionada (art. 103, $\S 3^{\circ}, \mathrm{CR}$ ), mas a própria PGR corroborando a constitucionalidade da lei estadual; em outros, o próprio Governador do Estado de onde proveio lei concluindo pela sua inconstitucionalidade. Em outros, ainda, foi possível, inclusive, observar órgãos ligados à União divergindo sobre a constitucionalidade de leis editadas pela própria União, com alguns desses corroborando a tese de agentes e órgãos estaduais. Uma hipótese interessante que o caso da ADI n ${ }^{\circ}$ 4.066/DF (em que se discutiu a constitucionalidade de disposição de lei editada pela União que autorizava, em determinadas hipóteses, atividades envolvendo amianto crisotila) sugere é a de que a probabilidade de o STF julgar procedente uma ADI que questiona a constitucionalidade de uma lei federal ou nacional aumenta 
quando não há coesão no posicionamento dos agentes e órgãos ligados à União que sobre aquela são chamados a se manifestar. Também foi possível observar, em alguns casos, a receptividade da Corte à interpretação constitucional feita por outros intérpretes da Constituição que não ela própria: os demais Tribunais, a AGU, a PGR, os chefes do Poder Executivo e o Poder Legislativo dos entes federativos, a OAB, entre outros. Todos esses elementos permitem colocar em perspectiva o resultado do julgamento, no sentido da procedência ou improcedência da ação no controle abstrato ou, de modo geral, do provimento ou desprovimento do recurso extraordinário no controle concreto de constitucionalidade. Esses dados, geralmente classificados com base em dois binômios o da (im)procedência da ação e o da origem (sub)nacional da lei -, ainda que relevantes, revelam muito pouco sobre o entendimento da Corte ou sobre como essa julga esses casos.

Para encerrar, cumpre analisar um último e importante aspecto: muitos observadores, incluindo Ministros do STF, têm apontado para o caráter excessivamente centralizado do Estado federal brasileiro, com alguns chegando inclusive a questionar se já não se teria ultrapassado a linha que o separa de um Estado unitário descentralizado. Viu-se aqui que a centralização do federalismo brasileiro pode ser, em boa medida, explicada por escolhas centralizadoras feitas pelos Constituintes (a extensão e o detalhamento dos catálogos de competências exclusivas e privativas da União são evidência disso), porém o STF pode ter intensificado ainda mais esse processo ao reverter escolhas dos Constituintes justo onde esses haviam tomado decisões descentralizadoras (relaxando as restrições impostas ao exercício da competência da União nas matérias de competência concorrente). Será que o passo derradeiro no sentido da centralização, aquele que teria o condão de transformar, na prática, a forma de Estado adotada na Constituição vigente - que, aliás, encontra-se protegida por cláusula pétrea, não podendo ser modificada nem pelo STF -, já não poderia ter sido dado justamente pelo órgão a quem essa confia a sua guarda? Embora instigante, essa questão é de difícil enfrentamento. Se é certo que o processo de centralização pode chegar, como de fato já chegou em outros períodos da história brasileira, a tal ponto de converter o Estado federal em um Estado unitário descentralizado, a literatura não parece ter chegado a um consenso acerca de onde fixar esse limite.

Os autores que recorrem a escalas contínuas de (des)centralização para descrever as diferenças entre as formas de Estados costumam limitar-se a dizer que o Estado federal situa-se entre o Estado unitário descentralizado, de um lado, e a Confederação de Estados, de outro, sem indicar exatamente onde esse intervalo se inicia e onde termina. Defendeu- 
se aqui que o grau (des)centralização não é um bom critério para distinguir Estados federais de Estados unitários. Afinal, como se sabe, há Estados federais mais centralizados do que muitos Estados unitários e Estados unitários mais descentralizados do que muitos Estados federais. Já os autores que procuraram identificar a essência do Estado federal para, assim, definir o critério distintivo entre as formas de Estado, costumam associá-lo ao princípio da não-subordinação entre os entes federativos. Isso que significa que aquele passo derradeiro seria dado no momento em que a União passa a ter o poder de sujeitar os Estados. Assim, considerando que, dentre o catálogo de competências concorrentes, encontram-se matérias importantes como Direito Tributário, Financeiro, Econômico, que certamente afetam a autonomia dos entes subnacionais, será que quando o STF, preocupado com as possíveis consequências da declaração de inconstitucionalidade de uma lei editada pela União a título de normas gerais, deixa de atentar aos limites impostos pelos Constituintes, não estaria dando justamente esse passo? Acredita-se que é precisamente essa questão com que se defrontam atualmente os Ministros do STF: até quando será possível manter essa postura de autocontenção, sem correr o risco de solapar as bases do Estado federal brasileiro? 


\section{REFERÊNCIAS BIBLIOGRÁFICAS}

ACKERMAN, Bruce. The failure of the founding fathers: Jefferson, Marshall, and the rise of the presidential democracy. Cambridge: Harvard University Press, 2005.

AJA, Eliseo. Estado autonómico y reforma federal. Madrid: Alianza Editorial, 2014.

ALBERTI ROVIRA, Enoch. Federalismo y cooperación en la República Federal alemana. Madrid: Centro de Estudios Constitucionales, 1986.

ALBERTI ROVIRA, Enoch. La representación territorial. Fundamentos: cuadernos monográficos de Teoría del Estado, Derecho Público e Historia Constitucional, n. 3, pp. 1-48, 2004.

ALMEIDA, Fernanda Dias Menezes de. Competências na Constituição de 1988. 4. ed. São Paulo: Atlas, 2013.

ALMEIDA, Fernando Dias Menezes de. Conflitos entre entes federativos: atuação do Supremo Tribunal Federal no regime da Constituição de 1988. In: MORAES, Alexandre de (coord.). Os 20 anos da Constituição da República Federativa do Brasil. São Paulo: Atlas, 2009.

ALMEIDA, Maria H. T. de. Federalismo, democracia e governo no Brasil: ideias, hipóteses e evidências. BIB, São Paulo, n. 51, pp. 13-34, 1. sem. 2001.

ALMEIDA, Maria H. T. de. Recentralizando a Federação? Revista de Sociologia e Política, 24, pp. 29-40, jun. 2005.

ANDERSON, George. Federalismo: uma introdução. Trad. Ewandro Magalhães Jr. e Fátima Guerreiro. Rio de Janeiro: Editora FGV, 2009.

ARAGÓN REYES, Manuel. La jurisprudencia del Tribunal Constitucional sobre las autonomías territoriales. Revista Vasca de Administración Pública, n. 10 (II), pp. 35-52, set./dez. 1984.

ARAGÓN REYES, Manuel. ¿Estado jurisdiccional autonómico? Revista Vasca de Administración Pública, n. 16, pp. 7-12, set./dez., 1986.

ARAÚJO, Marcelo Labanca Corrêa de. Jurisdição constitucional e Federação: o princípio da simetria na jurisprudência do STF. Rio de Janeiro: Elsevier, 2009.

ARONEY, Nicholas; KINCAID, John (Eds.). Courts in Federal Countries: federalists or unitarists? Toronto: University of Toronto Press, 2017.

ARRETCHE, Marta T. S. Estado federativo e políticas sociais: determinantes da descentralização. 3. ed. Rio de Janeiro: Revan, 2011.

ARRETCHE, Marta T. S. Democracia, federalismo e centralização no Brasil. Rio de Janeiro: Editora FGV; Editora Fiocruz, 2012. 
ARRETCHE, Marta T. S. Quando instituições federativas fortalecem o governo central? In: HOCHMAN, Gilberto \& FARIA, Carlos Aurélio Pimenta de (Orgs.). Federalismo e políticas públicas no Brasil. Rio de Janeiro: Fiocruz, 2013, pp. 65-90.

ARRETCHE, Marta; SCHLEGEL, Rogerio. Os estados nas federações: tendências gerais e o caso brasileiro. Documento para discussão. BID, fev. 2014. Disponível em: < https://www.resbr.net.br/wp-

content/uploads/historico/Os_estados_nas_federacoes_Tendencias_gerais_e_o_caso_brasileiro.pdf $>$ Data do acesso: 22/10/2018.

ATALIBA, Geraldo. República e Constituição. 2. ed. Atualizada por Rosolea Miranda Folgosi. 4. tir. São Paulo: Malheiros, 2007.

ATALIBA, Geraldo. Regime constitucional e leis nacionais e federais. In: CLÈVE, Clèmerson Merlin; BARROSO, Luís Roberto (Orgs.). Direito Constitucional. Coleção "doutrinas essenciais". Vol. III: Organização do Estado. 2. tir. São Paulo: Editora RT, 2011, pp. 285314.

BACHOF, Otto. Normas constitucionais inconstitucionais? Coimbra: Livraria Almedina, 1994.

BANKS, Christopher P.; BLAKEMAN, John C. The U.S. Supreme Court and new federalism: from the Rehnquist to the Roberts court. Lanham: Rowman \& Littlefield Publishers, 2012.

BARACHO, José Alfredo de Oliveira. Novos Rumos do Federalismo. Revista Brasileira de Estudos Políticos, Belo Horizonte, n. 56, pp. 97-134, 1983.

BARACHO, José Alfredo de Oliveira. Teoria Geral do Federalismo. Rio de Janeiro: Forense, 1986.

BARBOSA, Rui. Obras completas de Rui Barbosa. v. XVI e XVII. Rio de Janeiro: Ministério da Educação e Saúde, 1946.

BARBOSA, Rui. Anistia Inversa. In: BARBOSA, Rui. Obras completas de Rui Barbosa. v. XXIV (1897), t. III: Trabalhos jurídicos. Rio de Janeiro: Ministério da Educação e Saúde, 1955, pp. 1-196.

BARBOSA, Rui. Obras completas de Rui Barbosa. v. XXXVII (1910), t. V: O direito do Amazonas ao Acre Setentrional. Rio de Janeiro: Ministério da Educação e Saúde, 1983.

BARBOSA, Rui. Obras completas de Rui Barbosa. v. XLI (1914), t. III: Discursos parlamentares. Rio de Janeiro: Ministério da Educação e Saúde, 1974.

BARBOSA, Rui. O Supremo Tribunal Federal na Constituição Brasileira. In: BARBOSA, Rui. Obras completas de Rui Barbosa. v. XLI (1914), t. IV: Trabalhos jurídicos. Rio de Janeiro: Ministério da Educação e Saúde, 1989, pp. 223-255.

BARBOSA, Rui. Comentários à Constituição Federal brasileira. Coligidos e ordenados por Homero Pires. Vol. I: Das disposições preliminares. São Paulo: Saraiva, 1932.

BARBOSA, Rui. Atos inconstitucionais. Campinas: Russel editores, 2003. 
BARROSO, Luís Roberto. Direito constitucional brasileiro: o problema da Federação. Rio de Janeiro: Forense, 1982.

BARROSO, Luís Roberto. Interpretação e aplicação da Constituição: fundamentos de uma dogmática constitucional transformadora. 7. ed. São Paulo: Saraiva, 2013.

BARROSO, Luís Roberto. O direito constitucional e a efetividade de suas normas: limites e possibilidades da Constituição brasileira. 9. ed. Rio de Janeiro: Renovar, 2009.

BARROSO, Luís Roberto. O controle de constitucionalidade no direito brasileiro: exposição sistemática da doutrina e análise crítica da jurisprudência. 6. ed. São Paulo: Saraiva, 2012.

BARROSO, Luís Roberto. Curso de Direito Constitucional contemporâneo: os conceitos fundamentais e a construção do novo modelo. São Paulo: Saraiva, 2009.

BEDNAR, Jenna; ESKRIDGE JR., William N.; FEREJOHN, John. A Political Theory of Federalism. In: FEREJOHN, John; RAKOVE, Jack N.; RILEY, Jonathan (Eds.). Constitutional Culture and Democratic Rule. Cambridge: Cambridge University Press, 2001, pp. 223-67.

BEDNAR, Jenna. The robust federation: principles of design. Cambridge: Cambridge University Press, 2009.

BERCOVICI, Gilberto. Dilemas do Estado Federal brasileiro. Porto Alegre: Livraria do Advogado, 2004.

BLANCO VALDÉS, Roberto L. Los rostros del federalismo. Madrid: Alianza Editorial, 2012.

BLANCO VALDÉS, Roberto L. La construcción de la libertad: apuntes para una historia del constitucionalismo europeo. Madrid: Alianza editorial, 2010.

BLOCH, Susan Low; JACKSON, Vicki C. Federalism: a reference guide to the United States Constitution. Santa Barbara: Praeger, 2013.

BLUME, Lorenz; VOIGT, Stefan. Federalism and decentralization: a critical survey of frequently used indicators. Constitutional Political Economy, n. 22, pp. 238-264, 22 jan. 2011.

BRASIL. Assembleia Nacional Constituinte. Diário da Assembleia Nacional Constituinte. Brasília, 5 out. 1988, ano II, n. 308.

BRASIL. Assembleia Nacional Constituinte. Diário da Assembleia Nacional Constituinte. Suplemento "c". Ata da Comissão de Sistematização - 32a reunião extraordinária, 24 set. 1987. Brasília: Assembleia Nacional Constituinte, set. 1987.

BRASIL. Assembleia Nacional Constituinte. Projeto de Constituição (A). Emendas oferecidas em Plenário, vol. II (Emendas no 2P00949-2 a 2P02045-8). Brasília: Assembleia Nacional Constituinte, jan. 1988, vol. 255. 
BRASIL. Supremo Tribunal Federal (STF). A Constituição e o Supremo. 6. ed. atual. Brasília: STF, 2018.

BULMAN-POZEN, Jessica \& GERKEN, Heather K. Uncooperative federalism. The Yale Law Journal, v. 188, pp. 1256-1310, 2009.

BURGESS, Michael. Comparative federalism: theory and practice. New York: Routledge, 2006.

BURGESS, Michael. In search of the federal spirit: new theoretical and empirical perspectives in comparative federalism. New York: Oxford University Press, 2012.

BURGESS, Michael; TARR, G. Alan. (Eds.). Constitutional dynamics in federal systems: sub-national perspectives. [s.1.]: McGill-Queen's University Press; Forum of Federations, 2012 .

CALHOUN, John C. Selected writings and speeches. Ed. H. Lee Cheek Jr. Washington: Regnery Publishing Inc., 2003.

CALHOUN, John C. Libertad y Unión: La teoría de la Confederación. Madrid: Centro de Estudios Políticos y Constitucionales (CEPC), 2010.

CAPPELlETTI, Mauro. O controle judicial de constitucionalidade das leis no Direito Comparado. Trad. Aroldo Plínio Gonçalves. 2. ed., reimpr. Porto Alegre: Fabris, 1984.

CANOtilho, J. J. Gomes. Direito Constitucional e a Teoria da Constituição. 7. ed. Coimbra: Livraria Almedina, 2003.

CHOPER, Jesse H. The scope of national power vis-à-vis the States: the dispensability of judicial review. In: CHOPER, Jesse H. Judicial review and the national political process: a functional reconsideration of the role of the Supreme Court. New Orleans: Qui Pro Books, 2013.

CLÈVE, Clèmerson Merlin. A fiscalização abstrata de constitucionalidade no direito brasileiro. 2. ed., rev., atual. e ampl. 2. Tir. São Paulo: Revista dos Tribunais, 2000.

CLÈVE, Clèmerson Merlin; PEIXOTO, Marcela Moraes. O Estado brasileiro: algumas linhas sobre a divisão de poderes na federação brasileira à luz da Constituição de 1988. Revista de Informação Legislativa, Brasília, n. 104, pp. 21-42, 1989.

CORWIN, Edward. S. The passing of Dual Federalism. Virginia Law Review, vol. 36, n. 1, pp. 1-24, fev. 1950.

COSTA, Emília Viotti da. O Supremo Tribunal Federal e a construção da cidadania. 2. ed. São Paulo: Editora Unesp, 2006.

DALLARI, Dalmo de Abreu. O Estado Federal. São Paulo: Ática, 1986.

DARNSTÄDT, Thomas. La trampa del consenso. Trad. Juan Martínez de Luco Zelmer e Francisco Sosa Wagner. Madrid: Editorial Trotta, 2005. 
DAU-LIN, Hsü. Mutación de la Constitución. Trad. Pablo Lucas Verdú e Christian Förster. Oñati: Instituto Vasco de Administración Pública (IVAP), 1998.

DAVIS, S. Rufus. The federal principle: a journey through time in quest of meaning. Berkeley \& Los Angeles: University of California Press, 1978.

DUTRA, Carlos Roberto de Alckmin. Controle abstrato de constitucionalidade: análise dos princípios processuais aplicáveis. São Paulo: Saraiva, 2012.

DUTRA, Carlos Roberto de Alckmin. A exigência constitucional de qualidade formal da lei e seus reflexos no processo legislativo e no controle de constitucionalidade. 277 p. Tese (Doutorado em Direito). Faculdade de Direito (FDUSP), Universidade de São Paulo (USP), São Paulo, 2014.

ELAZAR, Daniel J. Exploring federalism. Tuscaloosa: The University of Alabama Press, 2006.

ENCINAR, José Juan González. Vocábulo “federalismo”. In: ENCINAR, José Juan González; NOHLEN, Dieter (Dir.): Diccionario del Sistema Político español. Madrid: Akal, 1984.

ENCINAR, José Juan González. El Estado unitario-federal: La autonomía como principio estructural del Estado. Madrid: Tecnos, 1985.

ESKRIDGE JR., William N.; BEDNAR, Jenna. Steadying the Court's "Unsteady Path": A Theory of Judicial Enforcement of Federalism. Southern California Law Review, vol. 68, pp. 1447-1491, 1994-1995.

ESKRIDGE JR., William N.; FRICKEY, Philip P. Quasi-Constitutional Law: clear statement rules as constitutional lawmaking. Vanderbilt Law Review, vol. 45, pp. 593-646, 1992.

ESKRIDGE JR., William N.; FEREJOHN, John. The elastic commerce clause: a political theory of American federalism. Vanderbilt Law Review, vol. 47, n. 5, pp. 1355-1400, 1994.

FALCÃO, Joaquim et al. II Relatório Supremo em Números: o Supremo e a Federação. Rio de Janeiro: Escola de Direito do Rio de Janeiro da Fundação Getúlio Vargas, 2013.

FALCÃO, Joaquim et al. II Relatório Supremo em Números: o Supremo e a Federação entre 2010 e 2012. Rio de Janeiro: Escola de Direito do Rio de Janeiro da Fundação Getúlio Vargas, 2014.

FERRARI, Diogo Augusto. Descentralização fiscal e repartição da receita pública: o FPE na Constituinte de 1988. 133 p. Dissertação (Mestrado em Ciência Política). Faculdade de Filosofia, Letras e Ciências Humanas (FFLCH), Universidade de São Paulo (USP), São Paulo, 2013.

FERRAZ, Anna Candida da Cunha. Processos informais de mudança da Constituição. 2. ed. Osasco: EdiFIEO, 2015. 
FERNÁNDEZ SEGADO, Francisco. La construcción jurisprudencial del Estado autonómico. Revista Vasca de Administración Pública, n. 27, pp. 47-112, mai./ago. 1990.

FERREIRA FILHO, Manoel Gonçalves. Curso de Direito Constitucional. 40. ed. São Paulo: Saraiva, 2015.

FERREIRA FILHO, Manoel Gonçalves. Aspectos do Direito Constitucional contemporâneo. 2. ed. Saraiva: São Paulo, 2013.

FRANCESE, Cibele; ABRUCIO, Fernando Luiz. Efeitos recíprocos entre federalismo e políticas públicas no Brasil: os casos dos sistemas de saúde, de assistência social e de educação. In: HOCHMAN, Gilberto \& FARIA, Carlos Aurélio Pimenta de (Orgs.). Federalismo e políticas públicas no Brasil. Rio de Janeiro: Fiocruz, 2013, pp. 361-386.

FRIEDRICH, Carl J. Federal Constitutional Theory and Emergent Proposals. In: MACMAHON, Arthur W (Coord.). Federalism: mature and emergent. New York: Doubleday \& Company, INC, 1955.

FRIEDRICH, Carl J. Trends of federalism in theory and practice. New York: Praeger Publishers, 1968.

GARCÍA-PELAYO, Manuel. Derecho Constitucional Comparado. Madrid: Alianza Editorial, 1999.

GERKEN, Heather K. Our Federalism(s). William and Mary Law Review, v. 53, n. 5, pp. 1549-1573, 2012.

GERKEN, Heather K. Federalism as the new nationalism: an overview. The Yale Law Journal, v. 123, n. 6, pp. 1889-1918, abr. 2014.

GERKEN, Heather K. Slipping the Bonds of federalism. Harvard Law Review, v. 128, n. 1, pp. 85-123, nov. 2014.

GERKEN, Heather K. Federalism 3.0. California Law Review, v. 105, n. 6, pp. 1695-1723, dez. 2017.

GOMES, Joaquim B. Barbosa. La Cour Suprême dans le système politique brésilien. Paris: Librairie Générale de Droit et de Jurisprudence, 1994.

GOMES, Sandra. O impacto das regras de organização do processo legislativo no comportamento dos parlamentares: um estudo de caso da Assembleia Nacional Constituinte (1987-1988). Dados - Revista de Ciências Sociais, v. 49, n. 1, pp. 193-224, 2006.

GREVE, Michael S. Against cooperative federalism. Mississippi Law Journal, v. 70, pp. 557-623, 2000.

GRODZINS, Morton. The American system. New Brunswick: Transaction Books, 1984.

HAMILTON, Alexander; MADISON, James; JAY, John. The Federalist Papers. New York: Signet Classic; Penguin Group, 2003. 
HAMILTON, Alexander; MADISON, James; JAY, John. O Federalista. Trad. Heitor de Almeida Herrera. Brasília: Editora Universidade de Brasília, 1984.

HESSE, Konrad. Elementos de Direito Constitucional da República Federal da Alemanha. Trad. Luís Afonso Heck. Porto Alegre: Sergio Antonio Fabris Editor, 1998.

HESSE, Konrad. El Estado Federal Unitário. Direito Público. Síntese, n. 50, pp. 9-36, mar./abr. 2013.

HOOGHE, Liesbet; MARKS, Gary; SCHAKEL, Arjan H. The Rise of Regional Authority: A Comparative Study of 42 Democracies (1950-2006). London: Routledge, 2010.

HORTA, Raul Machado. A autonomia do Estado-membro no Direito Constitucional brasileiro. Tese (cátedra de Direito Constitucional). Faculdade de Direito, Universidade de Minas Gerais (UFMG), Belo Horizonte, 1964.

HORTA, Raul Machado. Estrutura da Federação. Revista de Direito Público, ano. XX, n. 81, pp. 52-56, jan.-mar. 1987.

HORTA, Raul Machado. Direito Constitucional. 2. ed. rev., atual. e ampl. Belo Horizonte: Del Rey, 1999.

HORTA, Raul Machado. Direito Constitucional. 5. ed. rev. e atual. por Juliana Campos Horta. Belo Horizonte: Del Rey, 2010.

HUBER, Evelyne; RAGIN, Charles; STEPHENS, John D. Social democracy, Christian democracy, Constitutional structure, and the Welfare State. American Journal of Sociology, v. 99, n. 3, pp. 711-749, nov. 1993.

JUSTEN FILHO, Marçal. Comentários à Lei de licitações e contratos administrativos. 15. ed. São Paulo: Dialética, 2012.

KATZ, Ellis. Perspectivas contemporaneas del federalismo americano. Revista del Centro de Estudios Constitucionales, n. 1, pp. 13-31, set./dez. 1988.

KELSEN, Hans. Jurisdição constitucional. 3. ed. São Paulo: WMF Martins Fontes, 2016.

KELSEN, Hans. Teoria Geral do direito e do Estado. São Paulo: Martins Fontes, 2005.

KETCHAM, Ralph (Ed.). The Anti-Federalist Papers and the Constitutional Convention Debates. New York: Signet Classic; Penguin Group, 2003.

KING, Gary; KEOHANE, Robert O.; VERBA, Sidney. Designing Social Inquiry: scientific inference in qualitative research. Princeton: Princeton University Press, 1994.

KING, Preston. Federalism and Federation. Baltimore: The Johns Hopkins University Press, 1982. 
KLARMAN, Michael J. The Framers' Coup: the making of the United States Constitution. New York: Oxford University Press, 2016.

KRAMER, Larry D. Putting the politics back into the Political Safeguards of Federalism. Columbia Law Review, v. 100, n. 1, pp. 215-293, jan. 2000.

LaCROIX, Alison L. The ideological origins of American federalism. Cambridge: Harvard University Press, 2010.

LaCROIX, Alison L. The shadow powers of Article I. The Yale Law Journal, v. 123, n. 6, pp. 2044-2093, abr. 2014.

LaCROIX, Alison L. What if Madison had won? Imagining a Constitutional World of legislative supremacy. Indiana Law Review, v. 45, n. 1, pp. 41-59, 2011.

LE FUR, Louis. État Fédéral et Confédération d'États. Paris: Librairie Générale de Jurisprudence, 1896.

LEAL, Roger Stiefelmann. O efeito vinculante na Jurisdição Constitucional. São Paulo: Saraiva, 2006.

LEONCY, Léo Ferreira. Controle de constitucionalidade estadual: as normas de observância obrigatória e a defesa abstrata da Constituição do Estado-membro. São Paulo: Saraiva, 2007.

LEONCY, Léo Ferreira. "Princípio da simetria" e argumento analógico: o uso da analogia na resolução de questões federativas sem solução constitucional evidente. 189 p. Tese (Doutorado em Direito). Faculdade de Direito (FDUSP), Universidade de São Paulo (USP), São Paulo, 2011.

LEONCY, Léo Ferreira. Uma proposta de releitura do "princípio da simetria". Revista Consultor Jurídico (CONJUR). Disponível em: < http://www.conjur.com.br/2012-nov24/observatorio-constitucional-releitura-principio-simetria > Acessado em: 21/01/2017.

LEVINSON, Sanford V. Why I do not teach Marbury (except to Eastern Europeans) and why you shouldn’t either. Wake Forest Law Review, v. 38, pp. 553-578, 2003.

LEWANDOWSKI, Enrique Ricardo. Pressupostos Materiais e Formais da Intervenção Federal no Brasil. São Paulo: Revistas dos Tribunais, 1994.

LEWANDOWSKI, Enrique Ricardo. Considerações sobre o federalismo brasileiro. Justiça \& Cidadania, n. 157, pp. 14-17, set. 2013.

LIVINGSTON, William S. A note on the nature of federalism. Political Science Quarterly, v. 67, n. 1, pp. 81-95, mar. 1952.

LOEWENSTEIN, Karl. Teoría de la Constitución. 2. ed. Barcelona: Ariel, 1983.

LUTZ, Donald S. Toward a theory of constitutional amendment. The American Political Science Review, v. 88, n. 2, pp. 355-370, jun. 1994. 
LYNCH, Christian Edward Cyril. Togados da breca. Insight Inteligência, Rio de Janeiro, ano XV, n. 59, pp. 25-40, out./dez. 2012.

MADISON, James. The writings of James Madison. Vols. II (1783-1787) e V (1787-1790). Ed. Gaillard Hunt. New York: G. P. Putnam's Sons, 1901.

MADISON, James. The debates in the Federal Convention of 1787 which framed the Constitution of the United States of America. Eds. Gaillard Hunt \& James Brown Scott. New York: Oxford University Press, 1920.

MARINONI, Luiz Guilherme. Eficácia vinculante: a ênfase à ratio decidendi e à força obrigatória dos precedentes. Revista de processo (REPRO), v. 184, pp. 9-41, jul. 2010.

MARRAFON, Marco Aurélio. Julgamento de ADIs pelo Supremo promove centralização federativa. Revista Consultor Jurídico (CONJUR). Data da publicação: 27/01/2015. Disponível em: < http://www.conjur.com.br/2015-jan-27/constituicao-poder-julgamento-adissupremo-promovem-centralizacao-federativa $>$. Acessado em: 29/01/2015.

MARRAFON, Marco Aurélio; LIZIERO, Leonam Baesso da Silva. Competências da União e Supremo Tribunal Federal: fiadores da centralização no federalismo brasileiro. In: FISCHER, Octavio Campos (Coord.); SANTOS, Scheila Barbosa dos (Org.). Federalismo Fiscal e Democracia. Curitiba: Instituto Memória Editora, 2014, pp. 26-37.

McClOSKEY, Robert. G. The American Supreme Court. 6. ed. Rev. Sanford Levinson. Chicago: The University of Chicago Press, 2010.

MENDES, Gilmar Ferreira. Controle de constitucionalidade: aspectos jurídicos e políticos. São Paulo: Saraiva, 1990.

MENDES, Gilmar Ferreira. Controle abstrato de constitucionalidade: ADI, ADC e ADO: comentários à Lei n. 9.868/99. São Paulo: Saraiva, 2012.

MENDES, Gilmar Ferreira. Jurisdição Constitucional: o controle abstrato de normas no Brasil e na Alemanha. 6. ed. São Paulo: Saraiva, 2014.

MENDES, Gilmar Ferreira; COELHO, Inocêncio Mártires; BRANCO, Paulo Gustavo Gonet. Curso de Direito Constitucional. 12. ed. São Paulo: Saraiva, 2017.

MENDES, Gilmar Ferreira; MORAIS, Carlos Blanco de (Orgs.) Mutações constitucionais. São Paulo: Saraiva, 2016.

MELLO, Celso Antônio Bandeira de. Natureza e regime jurídico das autarquias. São Paulo: Revista dos Tribunais, 1968.

MELLO, Oswaldo Aranha Bandeira de. Natureza Jurídica do Estado Federal. São Paulo: Revista dos Tribunais, 1937.

MIRANDA, Jorge. Manual de Direito Constitucional. t. II. Constituição. 7. ed. Coimbra: Coimbra Editora, 2013. 
MIRANDA, Jorge. Manual de Direito Constitucional. t. III. Estrutura Constitucional do Estado. 6. ed. Coimbra: Coimbra Editora, 2010.

MIRANDA, Jorge. Manual de Direito Constitucional. t. VI. Inconstitucionalidade e garantia da Constituição. 6. ed. Coimbra: Coimbra Editora, 2015.

MIRANDA, Jorge. Contributo para uma teoria da inconstitucionalidade. Coimbra: Coimbra editora, 2007.

MIRANDA, Pontes de. Comentários à Constituição de 1946, v. I. 3. ed. rev. aum. Rio de Janeiro: Borsoi, 1960.

MITIDIERO, Daniel. Fundamentação e precedente - dois discursos a partir da decisão judicial. Revista de processo (REPRO), v. 206, pp. 61-78, abr. 2012.

MITIDIERO, Daniel. Cortes Superiores e Cortes Supremas: do controle à interpretação, da jurisprudência ao precedente. 3. ed., rev., atual. e ampl. São Paulo: Revista dos Tribunais, 2017.

MOHN, Paulo. Competência legislativa concorrente no Brasil: uma aplicação do princípio da subsidiariedade? In: CONSTITUIÇÃO de 1988: O Brasil 20 anos depois - o exercício da política, v. II. Brasília, Senado Federal, [s.d.].

MORAIS, Carlos Blanco de. Justiça Constitucional. Tomo I: Garantia da Constituição e controlo da constitucionalidade. 2. ed. Coimbra: Coimbra Editora, 2006.

MORAIS, Carlos Blanco de. Justiça Constitucional. Tomo II: O Direito do Contencioso Constitucional. 2. ed. Coimbra: Coimbra Editora, 2011.

MOREIRA, Egon Bockmann. Os 29 anos da Constituição que não é a de 1988. Gazeta do Povo. Curitiba, 10 out. 2017. Disponível em: < http://www.gazetadopovo.com.br/justica/colunistas/egon-bockmann-moreira/os-29-anosda-constituicao-que-nao-e-a-de-1988-dg3pxpk2482z6dferlmluhlrt $>$ Data do acesso: $14 / 10 / 2017$.

MOREIRA NETO, Diogo de Figueiredo. Competência concorrente limitada: o problema da conceituação das normas gerais. Revista de Informação Legislativa, Brasília, n. 100, pp. 127 162, out./dez. 1988.

MOUSKHELI, Michel. Teoría jurídica del Estado Federal. Trad. Armando Lázaro y Ros. 1. ed. México D. F.: Ediciones Coyoacán, 2011.

ORBINGER, Herbert; LEIBFRIED, Stephan; CASTLES, Francis G. Federalism and the Welfare State: New World and European Experiences. New York: Cambridge University Press, 2005.

PALERMO, Francesco; KÖSSLER, Karl. Comparative federalism: constitutional arrangements and case law. Portland: Hart Publishing, 2017. 
PONTES DE MIRANDA, Francisco Cavalcanti. Comentários à Constituição de 1967, com a emenda n. 1 de 1969. Tomos I e II. 2. ed., rev. 2. tir. São Paulo: Revista dos Tribunais, 1973.

PRADO, Sergio. A "federação inconclusa": o papel dos governos estaduais na federação brasileira. In: REZENDE, Fernando. O federalismo brasileiro em seu labirinto: crise e necessidade de reformas. Rio de Janeiro: FGV Editora, 2013, pp. 120-197.

RAMOS, Elival da Silva. A inconstitucionalidade das leis: vício e sanção. São Paulo: Saraiva, 1994.

RAMOS, Elival da Silva. A proteção dos direitos adquiridos no Direito Constitucional brasileiro. São Paulo: Saraiva, 2003.

RAMOS, Elival da Silva. A exigência de proporcionalidade no controle abstrato de normas brasileiro. Revista Mestrado em Direito, Osasco, ano 10, v. 1, pp. 115-139, jan./jun. 2010.

RAMOS, Elival da Silva. Controle de constitucionalidade no Brasil: perspectivas de evolução. São Paulo: Saraiva, 2010.

RAMOS, Elival da Silva. Ativismo judicial: parâmetros dogmáticos. 2. ed. São Paulo: Saraiva, 2015.

RAMOS, Elival da Silva; ALMEIDA, Fernanda Dias Menezes de. Auto-organização dos Estados federados. In: CLÈVE, Clèmerson Merlin; BARROSO, Luís Roberto (Orgs.). Direito Constitucional. Coleção "doutrinas essenciais”. Vol. III: Organização do Estado. 2. tir. São Paulo: Editora RT, 2011, pp. 447-459.

RESNIK, Judith. What's federalism for? In: BALKIN, Jack M. \& SIEGEL, Reva B. (Eds.). The Constitution in 2020. New York: Oxford University Press, 2009, pp. 269-284.

REZENDE, Fernando. A crise do federalismo brasileiro: evidências, causas e consequências. In: REZENDE, Fernando. O federalismo brasileiro em seu labirinto: crise e necessidade de reformas. Rio de Janeiro: FGV Editora, 2013, pp. 13-65.

RIKER. William H. Federalism: origin, operation, significance. Boston: Little, Brown and company, 1964.

RIKER. William H. Six books in search of a subject or does federalism exist and does it matter? Comparative Politics, v. 2, n. 1, pp. 135-146, out. 1969.

RIKER. William H. Federalism. In: GREENSTEIN, Fred I.; POLSBY, Nelson W. (Ed.) Handbook of Political Science. Vol. 5: governmental institutions and processes. Reading: Addison-Wesley Publishing Company, pp. 93-172.

RIKER. William H. The development of American Federalism. Norwell: Kluwer Academic Publishers, 1987.

ROCHA, Cármen Lúcia Antunes. República e Federação no Brasil: traços constitucionais da organização política brasileira. Belo Horizonte: Del Rey, 1996. 
RODDEN, Jonathan A. Federalismo e descentralização em perspectiva comparada: sobre significados e medidas. Revista de Sociologia e Política, Curitiba, n. 24, pp. 9-27, jun. 2005.

RODDEN, Jonathan A. Hamilton's Paradox: the promise and peril of fiscal federalism. New York: Cambridge University Press, 2006.

ROSSUM, Ralph A. Federalism, the Supreme Court and Seventh Amendment: the irony of constitutional democracy. Lanham: Lexington Books, 2001.

RUBIO LLORENTE, Francisco. La jurisdicción constitucional en los conflictos entre el poder central y los poderes territoriales. Revista Vasca de Administración Pública, n. 10 (II), pp. 11-23, set./dez. 1984.

SCHMITT, Carl. Teoría de la Constitución. Madrid: Alianza editorial, 2003.

SCHMITT, Carl. O guardião da Constituição. Belo Horizonte: Del Rey, 2007.

SCHNEIDER, Hans-Peter; KRAMER, Jutta; TORITTO, Beniamino Caravita di (Eds.). Judge made federalism?: The role of Courts in Federal Systems. Baden-Baden: Nomos, 2009.

SCHWARTZ, Bernard. O federalismo norte-americano atual: uma visão contemporânea. Trad. Elcio Cerqueira. Rio de Janeiro: Forense Universitária, 1984.

SCHWARTZ, Bernard. A History of the Supreme Court. New York: Oxford University Press, 1993.

SILVA, José Afonso da. Curso de Direito Constitucional Positivo. 26. ed. São Paulo: Malheiros, 2017.

SILVEIRA, Alessandra. Cooperação e compromisso constitucional nos Estados compostos: estudo sobre a teoria do federalismo e a organização jurídica dos sistemas federativos. Coimbra: Livraria Almedina, 2007.

SOUZA, Celina. Federalismo e descentralização na Constituição de 1988: processo decisório, conflitos e alianças. Dados - Revista de Ciências Sociais, v. 44, n. 3, pp. 513-560, 2001.

SOUZA, Celina. Federalismo, desenho constitucional e instituições federativas no Brasil pós-1988. Revista de Sociologia e Política, 24, pp. 105-121, jun. 2005.

SOUZA, Celina. Federalismo: teorias e conceitos revisitados. BIB, São Paulo, n. 65, pp. 27-48, 1. sem. 2008.

SOUZA, Celina. Instituições e mudanças: reformas da Constituição de 1988, federalismo e políticas públicas. In: HOCHMAN, Gilberto \& FARIA, Carlos Aurélio Pimenta de (Orgs.). Federalismo e políticas públicas no Brasil. Rio de Janeiro: Fiocruz, 2013, pp. 91-118.

SOUZA, Celina. Para entender a nossa barafunda federativa. Insight Inteligência, Rio de Janeiro, ano XVI, n. 61, pp. 61-70, abr./jun. 2013. 
SOUZA JUNIOR, Cezar Saldanha; REVERBEL, Carlos Eduardo Dieder. O Tribunal Constitucional como Poder: uma nova visão dos Poderes políticos. 2. ed., rev., atual. e ampl. São Paulo: Revista dos Tribunais, 2016.

STEPAN, Alfred. Para uma nova análise comparativa do federalismo e da democracia: Federações que restringem ou ampliam o poder do Demos. Dados, vol. 42, n. 2, 1999.

STEPAN, Alfred. Federalism and democracy: beyond the U.S. model. Journal of democracy, vol. 10, n. 4, pp. 19-32, out. 1999.

STEPAN, Alfred. Brazil's decentralized federalism: bringing government closer to the citizens? Daedalus, vol. 129, n. 2, pp. 145-170, primavera, 2000.

TARUFFO, Michele. Precedente e jurisprudência. Revista de processo (REPRO), v. 199, pp. 139-155, set. 2011.

TEIXEIRA, J. H. Meirelles. Curso de Direito Constitucional. Rio de Janeiro: Forense Universitária, 1991.

TEMER, Michel. Elementos de Direito Constitucional. 24. ed. 4 tir. São Paulo: Malheiros, 2017.

TOMIO, Fabricio Ricardo de Limas; ROBL FILHO, Ilton Norberto. Empirical Legal Research: teoria e metodologia para a abordagem do processo decisório de controle de constitucionalidade no STF. In: VESTENA, Carolina Alves; SIQUEIRA, Gustavo Silveira. Direito e experiências jurídicas. Vol. II: debates práticos. Belo Horizonte: Arraes Editores, 2013, pp. 96-117.

TOMIO, Fabricio Ricardo de Limas; ROBL FILHO, Ilton Norberto; KANAYAMA, Rodrigo Luis. Constitucionalismo estadual e controle abstrato e concentrado de constitucionalidade nos Tribunais de Justiça: efeitos das ações diretas de inconstitucionalidade (ADI) estaduais na Federação brasileira. Revista de Direito brasileira, ano 5, v. 12, pp. 87-110, 2015.

TOCQUEVILlE, Alexis de. A democracia na América: leis e costumes. 2. ed. São Paulo: Martins Fontes, 2005.

TSEBELLIS, George. Veto players and institutional analysis. Governance: an International Journal of Policy and Administration, v. 13, n. 4, pp. 441-474, out. 2000.

WATTS, Ronald L. Comparing federal systems. 3. ed. Kingston: McGill-Queen's University Press, 2008.

WECHSLER, Herbert. The Political Safeguards of Federalism: the role of the States in the composition and selection of the National government. Columbia Law Review, v. 54, n. 4, pp. 530-560, abr. 1954.

WHEARE, K. C. Federal government. 4. ed. London: Oxford University Press, 1963. YOUNG, Ernest. Two cheers for Process Federalism. Villanova Law Review, v. 46, n. 5, pp. 1349-1396, 2001. 
ZAVASCKI, Teori Albino. Eficácia das sentenças na Jurisdição Constitucional. 4. ed., rev., atual. e ampl. São Paulo: Revista dos Tribunais, 2017.

\section{LEGISLAÇÃO NACIONAL}

BRASIL. Decreto nº 1. Rio de Janeiro: Governo Provisório, 16 nov. 1889.

BRASIL. Constituição da República dos Estados Unidos do Brasil. Rio de Janeiro: Congresso Nacional Constituinte, 24 fev. 1891.

BRASIL. Decreto-Lei nº 667. Brasília: Presidência da República, 2 jul. 1969.

BRASIL. Emenda Constitucional nº 1. Brasília: Congresso Nacional, 17 out. 1969.

BRASIL. Lei no 5.692 (Lei de Diretrizes e Bases da Educação Nacional). Brasília: Congresso Nacional, 11 ago. 1971.

BRASIL. Lei $n^{\circ}$ 6.880. Brasília: Congresso Nacional, 9 dez. 1980.

BRASIL. Constituição da República Federativa do Brasil de 1988. Brasília: Assembleia Nacional Constituinte, 5 out. 1988.

BRASIL. Lei $n^{o}$ 8.078. Brasília: Congresso Nacional, 11 set. 1990.

BRASIL. Lei $n^{\circ} 8.666$ (Lei Geral de Licitações e Contratos Administrativos). Brasília: Congresso Nacional, 21 jun. 1993.

BRASIL. Lei $n^{o}$ 8.883. Brasília: Congresso Nacional, 8 jun. 1994.

BRASIL. Lei $n^{\circ}$ 9.055. Brasília: Congresso Nacional, $1^{\circ}$ jun. 1995.

BRASIL. Lei $n^{\circ} 9.394$ (Lei de Diretrizes e Bases da Educação Nacional). Brasília: Congresso Nacional, 20 dez. 1996.

BRASIL. Lei $n^{\circ}$ 9.424. Brasília: Congresso Nacional, 24 dez. 1996.

BRASIL. Lei $n^{\circ}$ 9.717. Brasília: Congresso Nacional, 27 nov. 1998.

BRASIL. Lei $n^{\circ}$ 9.868 (Lei da ADI e da ADC). Brasília: Congresso Nacional, 10 nov. 1999.

BRASIL. Lei complementar $n^{o} 101$ (Lei de Responsabilidade Fiscal). Brasília: Congresso Nacional, 4 mai. 2000.

BRASIL. Lei $n^{\circ}$ 10.029. Brasília: Congresso Nacional, 20 out. 2000.

BRASIL. Decreto $n^{\circ}$ 3.788. Brasília: Presidência da República, 11 abr. 2001.

BRASIL. Decreto $n^{\circ}$ 4.680. Brasília: Presidência da República, 24 abr. 2003.

BRASIL. Lei $n^{\circ}$ 11.161. Brasília: Congresso Nacional, 05 ago. 2005. 
DISTRITO FEDERAL. Lei nº 9.262. Brasília: Câmara Legislativa, 12 jan. 1996.

DISTRITO FEDERAL. Lei $n^{\circ}$ 2.921. Brasília: Câmara Legislativa, 22 fev. 2002.

DISTRITO FEDERAL. Lei nº 3.694. Brasília: Câmara Legislativa, 8 nov. 2005.

DISTRITO FEDERAL. Lei nº 5.345. Brasília: Câmara Legislativa, 20 mai. 2014.

MATO GROSSO. Lei n 7.478. Cuiabá: Assembleia Legislativa, 20 jul. 2001.

MATO GROSSO DO SUL. Lei Complementar (LC) $n^{\circ}$ 68. Campo Grande: Assembleia Legislativa, 8 jul. 1993.

MATO GROSSO DO SUL. Lei $n^{\circ}$ 2.210. Campo Grande: Assembleia Legislativa, 5 jan. 2001.

MINAS GERAIS. Lei no 14.507. Belo Horizonte: Assembleia Legislativa, 20 dez. 2002.

PARANÁ. Lei $n^{\circ}$ 9.056. Curitiba: Assembleia Legislativa, 2 ago. 1989.

PARANÁ. Lei $n^{\circ}$ 9.346. Curitiba: Assembleia Legislativa, 23 jul. 1990.

PARANÁ. Lei $n^{\circ}$ 14.861. Curitiba: Assembleia Legislativa, 27 out. 2005.

PERNAMBUCO. Lei $n^{\circ}$ 12.589. Recife: Assembleia Legislativa, 26 mai. 2004.

RIO DE JANEIRO. Lei n ${ }^{\circ}$ 3.579. Rio de Janeiro: Assembleia Legislativa, 07 jun. 2001.

RIO GRANDE DO SUL. Lei nº 7.747. Porto Alegre: Assembleia Legislativa, 22 dez. 1982.

RIO GRANDE DO SUL. Lei nº 11.643. Porto Alegre: Assembleia Legislativa, 21 jun. 2001.

RIO GRANDE DO SUL. Lei n 11.871. Porto Alegre: Assembleia Legislativa, 19 dez. 2002.

RORAIMA. Lei no 430. Boa Vista: Assembleia Legislativa, 16 abr. 2004.

SANTA CATARINA. Lei $n^{\circ}$ 1.179. Florianópolis: Assembleia Legislativa, 21 dez. 1994.

SANTA CATARINA. Lei Complementar $(L C) n^{\circ} 170$. Florianópolis: Assembleia Legislativa, 7 ago. 1998.

SÃO PAULO. Lei no 9.164. São Paulo: Assembleia Legislativa, 17 mai. 1995.

SÃO PAULO. Lei no 10.813. São Paulo: Assembleia Legislativa, 24 mai. 2001.

SÃO PAULO. Lei no 12.684. São Paulo: Assembleia Legislativa, 26 jul. 2007.

SÃO PAULO. Lei ño 13.113. São Paulo: Câmara Municipal, 16 mar. 2001. 
BELO HORIZONTE. Lei nº 4.253/1985. Belo Horizonte: Câmara Municipal, 6 dez. 1985.

BELO HORIZONTE. Decreto nº 5.893/1988. Belo Horizonte: Prefeitura Municipal, 18 mar. 1988.

\section{LEGISLAÇÃO ESTRANGEIRA}

ALEMANHA. Lei Fundamental da República Federal da Alemanha. Trad. Assis Mendonça, Aachen. Rev. jur. Urbano Carvelli, Bonn. Berlim: Deutscher Bundestag, 2011.

ETIÓPIA. Constituição da Etiópia de 1994.

ESTADOS UNIDOS DA AMÉRICA. Constituição dos Estados Unidos da América. Bedford: The National Archives, [s.d.]

FRANÇA. Constituição de 1958. Paris: L’Assamblée nationale, 1958.

SUÍÇA. Constituição federal da Confederação suiça.

UNIÃO EUROPEIA. Tratado da União Europeia (versão em português). Jornal Oficial da União Europeia, 7 jun. 2016.

\section{JURISPRUDÊNCIA NACIONAL}

BRASIL. Supremo Tribunal Federal (STF). Representação de Inconstitucionalidade (Rp) $n^{o}$ 1153/RS. Relator: Min. Aldir Passarinho. Brasília, 16 mai. 1985. DJ 25-10-1985, p. 19145.

BRASIL. Supremo Tribunal Federal (STF). Medida Cautelar na Ação Direta de Inconstitucionalidade (ADI-MC) $n^{o}$ 1278/SC. Relator: Min. Marco Aurélio. Brasília, 18 mai. 1995. DJ 14-06-2002, p. 126.

BRASIL. Supremo Tribunal Federal (STF). Ação Declaratória de Constitucionalidade (ADC) $n^{o}$ 1/DF. Relator: Min. Moreira Alves. Brasília, 01 dez. 1993. DJ 16-06-1995, p. 18213.

BRASIL. Supremo Tribunal Federal (STF). Medida Cautelar na Ação Direta de Inconstitucionalidade (ADI-MC) $n^{\circ}$ 927/RS. Relator: Min. Carlos Velloso. Brasília, 03 nov. 1993. DJ 11-11-1994, p. 30635.

BRASIL. Supremo Tribunal Federal (STF). Medida Cautelar na Ação Direta de Inconstitucionalidade (ADI-MC) $n^{\circ}$ 933/GO. Relator: Min. Carlos Velloso. Brasília, 04 nov. 1993. DJ 25-02-1994, p. 02591.

BRASIL. Supremo Tribunal Federal (STF). Ação Direta de Inconstitucionalidade (ADI) $n^{o}$ 1540/MS. Relator: Min. Maurício Corrêa. Brasília, 25 jun. 1997. DJ 16/11/2001, p. 7.

BRASIL. Supremo Tribunal Federal (STF). Medida Cautelar na Ação Direta de Inconstitucionalidade (ADI-MC) $n^{o}$ 1627/DF. Relator: Min. Octavio Gallotti. Brasília, 30 jun. 1997. DJ 24/10/1997, p. 54156. 
BRASIL. Supremo Tribunal Federal (STF). Medida Cautelar na Ação Direta de Inconstitucionalidade (ADI-MC) $n^{\circ}$ 2667/DF. Relator: Min. Celso de Mello. Brasília, 19 jun. 2002. DJ 12/03/2004, p. 38.

BRASIL. Supremo Tribunal Federal (STF). Ação Direta de Inconstitucionalidade (ADI) $n^{o}$ 252/PR. Relator: Min. Moreira Alves. Brasília, 20 nov. 1997. DJ 21-02-2003, p. 29.

BRASIL. Supremo Tribunal Federal (STF). Ação Direta de Inconstitucionalidade (ADI) $n^{o}$ 384/PR. Relator: Min. Moreira Alves. Brasília, 20 nov. 1997. DJ 21-02-2003, p. 29.

BRASIL. Supremo Tribunal Federal (STF). Medida Cautelar na Ação Direta de Inconstitucionalidade (ADI-MC) $n^{\circ}$ 2535/MT. Relator: Min. Sepúlveda Pertence. Brasília, 19 dez. 2001. DJ 21/11/2003, p. 8.

BRASIL. Supremo Tribunal Federal (STF). Ação Direta de Inconstitucionalidade (ADI) $n^{o}$ 2396/MS. Relatora: Minª Ellen Gracie. Brasília, 08 mai. 2003. DJ 01/08/2003, p. 107.

BRASIL. Supremo Tribunal Federal (STF). Ação Direta de Inconstitucionalidade (ADI) $n^{o}$ 2656/SP. Relator: Min. Maurício Corrêa. Brasília, 08 mai.2003. DJ 01-08-2003, p. 107.

BRASIL. Supremo Tribunal Federal (STF). Medida Cautelar na Ação Direta de Inconstitucionalidade (ADI-MC) $n^{\circ}$ 3059/RS. Relator: Min. Ayres Britto. Brasília, 15 abr. 2004. DJ 20-08-2004, p. 37.

BRASIL. Supremo Tribunal Federal (STF). Ação Direta de Inconstitucionalidade (ADI) $n^{o}$ 1399/SP. Relator: Min. Maurício Corrêa. Brasília, 03 mar. 2004. DJ 11/06/2004, p. 4.

BRASIL. Supremo Tribunal Federal (STF). Ação Direta de Inconstitucionalidade (ADI) $\mathrm{n}^{\mathbf{0}}$ 2895/AL. Relator: Min. Carlos Velloso, Brasília, 02 fev. 2005. DJ 20-05-2005, p. 5.

BRASIL. Supremo Tribunal Federal (STF). Recurso Extraordinário (RE) $n^{o}$ 286789/RS. Relatora: Mina Ellen Gracie. Brasília, 08 mar. 2005. DJ 08/04/2005, p. 00038.

BRASIL. Supremo Tribunal Federal (STF). Medida Cautelar na Ação Direta de Inconstitucionalidade (ADI-MC) $n^{o}$ ADI 3322/DF. Relator: Min. Cezar Peluso. Brasília, 02 ago. 2006. DJ 19-12-2006, p. 35.

BRASIL. Supremo Tribunal Federal (STF). Ação Direta de Inconstitucionalidade (ADI) $n^{\circ}$ 3645/PR. Relatora: Mina Ellen Gracie. Brasília, 31 mai. 2006. DJ 01/09/2006, p. 16.

BRASIL. Supremo Tribunal Federal (STF). Medida Cautelar na Ação Direta de Inconstitucionalidade (ADI-MC) $n^{o}$ 3774/RR. Relator: Min. Joaquim Barbosa. Brasília, 25 out. 2006. DJe $\mathrm{n}^{\mathrm{o}}$ 013, divulgado em 10/05/2007 e publicado em 11/05/2007.

BRASIL. Supremo Tribunal Federal (STF). Ação Direta de Inconstitucionalidade (ADI) $n^{o}$ 2990/DF. Relator: Min. Joaquim Barbosa. Relator para o acórdão: Min. Eros Grau. Brasília, 18 abr. 2007. DJe n ${ }^{\circ}$ 087, divulgado em 23/08/2007 e publicado em 24/08/2007. 
BRASIL. Supremo Tribunal Federal (STF). Ação Direta de Inconstitucionalidade (ADI) $n^{o}$ 682/PR. Relator: Min. Maurício Corrêa, Relator para o acórdão: Min. Joaquim Barbosa. Brasília, 08 mar. 2007. DJe n ${ }^{\circ}$ 013, divulgado em 10/05/2007 e publicado em 11/05/2007.

BRASIL. Supremo Tribunal Federal (STF). Ação Direta de Inconstitucionalidade (ADI) $n^{\circ}$ 3669/DF. Relatora: Min ${ }^{a}$ Cármen Lúcia. Brasília, 18 jun. 2007. DJe nº 047, divulgado em 28/06/2007 e publicado em 29/06/2007.

BRASIL. Supremo Tribunal Federal (STF). Ação Direta de Inconstitucionalidade (ADI) $n^{o}$ 2999. Relator: Min. Gilmar Mendes. Brasília, 13 mar. 2008. DJe n ${ }^{\circ}$ 089, divulgado em 14/05/2009 e publicado em 15/05/2009.

BRASIL. Supremo Tribunal Federal (STF). Medida Cautelar na Ação Direta de Inconstitucionalidade (ADI-MC) $n^{\circ}$ 2238/DF. Relator: Min. Ilmar Galvão. Brasília, 09 ago. 2007. DJe $n^{\text {o }} 172$, divulgado em 11/09/2008 e publicado em 12/09/2008.

BRASIL. Supremo Tribunal Federal (STF). Tutela Antecipada - Referendo Ação Cível Originária (ACO-TAR) $n^{\circ}$ 830/PR. Relator: Min. Marco Aurélio. Brasília, 29 out. 2007. DJe $\mathrm{n}^{\mathrm{o}}$ 065, divulgado em 10/04/2008 e publicado em 11/04/2008.

BRASIL. Supremo Tribunal Federal (STF). Medida Cautelar na Ação Direta de Inconstitucionalidade (ADI-MC) $n^{o}$ 3937/SP. Relator: Min. Marco Aurélio. Brasília, 04 jun. 2008. DJe $n^{\text {o }} 192$, divulgado em 09/10/2008 e publicado em 10/10/2008.

BRASIL. Supremo Tribunal Federal (STF). Recurso Extraordinário (RE) $n^{\circ}$ 377457/PR. Relator: Min. Gilmar Mendes. Brasília, 17 set. 2008. DJe n 241, divulgado em 18/12/2008 e publicado em 19/12/2008.

BRASIL. Supremo Tribunal Federal (STF). Medida Cautelar na Ação Direta de Inconstitucionalidade (ADI-MC) $n^{\circ} 4638 / \mathrm{DF}$. Relator: Min. Marco Aurélio. Brasília, julgado 08 fev. 2012. DJe n ${ }^{\circ} 213$, divulgado em 29/10/2014 e publicado 30/10/2014.

BRASIL. Supremo Tribunal Federal (STF). Reclamação (Rcl) $n^{\circ} 4335 / A C$. Relator: Min. Gilmar Mendes. Brasília, 20 mar. 2014. DJe no 208, divulgado em 21/10/2014 e publicado em $22 / 10 / 2014$.

BRASIL. Supremo Tribunal Federal (STF). Ação Direta de Inconstitucionalidade (ADI) $n^{o}$ 4060/SC. Relator: Min. Luiz Fux. Brasília, 25 fev. 2015. DJe $n^{\circ}$ 081, divulgado em 30/04/2015 e publicado em 04/05/2015.

BRASIL. Supremo Tribunal Federal (STF). Ação Direta de Inconstitucionalidade (ADI) $n^{o}$ 1627/DF. Relatora: Min ${ }^{a}$ Cármen Lúcia. Brasília, 18 ago. 2016. DJe nº 241, divulgado em 11/11/2016 e publicado em 14/11/2016.

BRASIL. Supremo Tribunal Federal (STF). Ação Direta de Inconstitucionalidade (ADI) $n^{o}$ 2905/MG. Relator: Min. Eros Grau. Relator para o acórdão: Min. Marco Aurélio. Brasília, 16 nov. 2016. DJe $\mathrm{n}^{\circ} 019$, divulgado em 01/02/2018 e publicado em 02/02/2018. 
BRASIL. Supremo Tribunal Federal (STF). Ação Direta de Inconstitucionalidade (ADI) $n^{o}$ 4764/AC. Relator para o acórdão: Min. Roberto Barroso. Brasília, 04 mai. 2017. DJe $\mathrm{n}^{\circ}$ 178, divulgado em 14 ago. 2017 e publicado em 15 ago. 2017.

BRASIL. Supremo Tribunal Federal (STF). Repercussão Geral no Recurso Extraordinário (RE-RG) $n^{\circ}$ 1007271/PE. Relator: Min. Edson Fachin. Brasília, 12 out. 2017. DJe no 257, divulgado em 10/11/2017 e publicado em 13/11/2017.

BRASIL. Supremo Tribunal Federal (STF). Recurso Extraordinário (RE) $n^{\circ}$ 194.704/MG. Relator: Min. Carlos Velloso. Redator do acórdão: Min. Edson Fachin. Brasília, 29 jun. 2017. DJe no 261/2017, divulgado em 16 nov. 2017 e publicado em 17 nov. 2017.

BRASIL. Supremo Tribunal Federal (STF). Ação Direta de Inconstitucionalidade (ADI) $n^{o}$ 4066/DF. Relatora: Min ${ }^{a}$ Rosa Weber. Brasília, 24 ago. 2017. DJe $n^{\circ} 043$, divulgado em 06/03/2018 e publicado em 07/03/2018.

BRASIL. Supremo Tribunal Federal (STF). Ação Direta de Inconstitucionalidade (ADI) $n^{o}$ 3937/SP. Relator: Min. Marco Aurélio. Relator para o acórdão: Min. Dias Toffoli. Brasília, 24 ago. 2017. DJe n ${ }^{\circ}$ 019, divulgado em 31/01/2019 e publicado em 01/02/2019.

BRASIL. Supremo Tribunal Federal (STF). Ação Direta de Inconstitucionalidade (ADI) $n^{o}$ 3406/RJ. Relatora: Min ${ }^{a}$ Rosa Weber. Brasília, 29 nov. 2017. DJe no 019, divulgado em 31/01/2019 e publicado em 01/02/2019.

BRASIL. Supremo Tribunal Federal (STF). Ação Direta de Inconstitucionalidade (ADI) $n^{o}$ 3470/RJ. Relatora: Min ${ }^{a}$ Rosa Weber. Brasília, 29 nov. 2017. DJe $n^{\circ}$ 019, divulgado em 31/01/2019 e publicado em 01/02/2019.

BRASIL. Supremo Tribunal Federal (STF). Arguição de Descumprimento de Preceito Fundamental (ADPF) $n^{\circ}$ 109/SP. Relator: Min. Edson Fachin. Brasília, 30 nov. 2017. DJe $\mathrm{n}^{\circ} 019$, divulgado em 31/01/2019 e publicado em 01/02/2019.

BRASIL. Supremo Tribunal Federal (STF). Ação Direta de Inconstitucionalidade (ADI) $n^{o}$ 3357/RS. Relator: Min. Ayres Britto. Relator para o acórdão: Min. Dias Toffoli. Brasília, 30 nov. 2017. DJe ${ }^{\circ} 019$, divulgado em 31/01/2019 e publicado em 01/02/2019.

BRASIL. Supremo Tribunal Federal (STF). Ação Direta de Inconstitucionalidade (ADI) $n^{o}$ 3356/PE. Relator: Min. Eros Grau. Relator para o acórdão: Min. Dias Toffoli. Brasília, 30 nov. 2017. DJe $n^{\circ} 019$, divulgado em 31/01/2019 e publicado em 01/02/2019.

BRASIL. Supremo Tribunal Federal (STF). Repercussão Geral no Recurso Extraordinário (RE$R G) n^{o} 1188352 / D F$. Relator: Min. Luiz Fux. Brasília, 14 mar. 2019. DJe $n^{\circ} 056$, divulgado em 21/03/2019 e publicado em 22/03/2019.

\section{JURISPRUDÊNCIA ESTRANGEIRA}

ESTADOS UNIDOS DA AMÉRICA. Suprema Corte dos EUA. Marbury v. Madison, 1 Cranch 137 (1803).

ESTADOS UNIDOS DA AMÉRICA. Suprema Corte dos EUA. National League of Cities v. Usery, 426 U. S. 833 (1976) 
ESTADOS UNIDOS DA AMÉRICA. Suprema Corte dos EUA. Garcia v. San Antonio Metropolitan Transit Authority, 469 U. S. 528 (1985).

ESTADOS UNIDOS DA AMÉRICA. Suprema Corte dos EUA. New York v. United States, 505 U. S. 144 (1992).

ESTADOS UNIDOS DA AMÉRICA. Suprema Corte dos EUA. United States v. Lopez, 514 U. S. 549 (1995).

ESTADOS UNIDOS DA AMÉRICA. Suprema Corte dos EUA. United States v. Morrison, 529 U. S. 598 (2000). 